\title{
O URBANISMO DO INÍCIO DO SÉCULO XX: A ESCOLA FRANCESA DE URBANISMO E SUAS REPERCUSSÕES NO BRASIL: TRAJETÓRIAS DE ALFRED AGACHE E ATTILIO CORREA LIMA
}

\author{
Marlice Nazareth Soares Azevedo, Milena Sampaio da Costa
}

\section{Resumo}

O trabalho busca fazer um paralelo entre a tese de doutorado de Attilio Correa Lima Avant Projet d'aménagement et extension de de la ville de Niterói au Brésil - e o Plano de Remodelação, Extensão e Embelezamento da Cidade do Rio de Janeiro, elaborado por Agache, ambos realizados no mesmo período e concluídos em 1930. Na concepção desses trabalhos, o urbanismo é visto como instrumento de transformação da cidade, baseando-se na idéia de que o conhecimento técnico e científico pode responder, por si só, a necessidade de resolução de problemas urbanos. Essa corrente, que vem desde o início do século XX e prolonga-se até a década de 1970, está associada, no caso brasileiro, a governos fortes, intervencionistas, que tratam a cidade de forma global, acreditando ser capaz de, através do planejamento, controlar e guiar as transformações urbanas.

\section{Palavras-chave:}

Rio de Janeiro; Niterói; planos de remodelação, extensão e embelezamento.

\section{Abstract}

The paper pretends to draw a parallel between the doctoral thesis of Attilio Correa Lima - Avant Projet d'extension aménagement et de la ville de Niterói au Brésil - and the Plano de Remodelação, Extensão e Embelezamento da Cidade do Rio de Janeiro, from Agache, both developed in the same period and completed in 1930. For these studies, urbanism is seen as an instrument of transformation of the city, based on the idea that the technical and scientific knowledge can answer, alone, the urban problems. This current, which comes from the early twentieth century and extends into the 1970s, is associated, in the Brazilian case, the strong's interventionists governments, who treat the city as a whole, believing be able to, through the planning, control and guide the urban transformations. 


\section{Keywords}

Rio de Janeiro; Niterói; redevelopment, extension and beautification plans.

\section{Introdução}

A tese de doutorado de Attilio estava imbuída dos princípios do urbanismo desenvolvidos pelos professores reunidos em torno do Instituto de Urbanismo da Universidade de Paris, que tiveram uma vasta atuação profissional na Europa e norte da África. Defendida em 1930, a tese teve pouca divulgação no Brasil, na época, mas através da forte atuação deste Urbanista até sua precoce morte, em 1943, seus princípios puderam ser reinterpretados nos diversos planos em que ele se envolveu neste período.

O Plano para a cidade do Rio de Janeiro foi desenvolvido por Alfred Agache, por ocasião do convite do, então, prefeito da cidade do Rio de Janeiro, Prado Junior, em 1927. Foi o primeiro plano orientado para a totalidade da cidade, destacando-se a monumentalidade e o forte academicismo presentes, traços da École de Beaux-Arts de Paris e do movimento City Beautiful. Antecedeu-se ao Plano um ciclo de conferências que buscou apresentar os temas de urbanismo ao público geral, assim como justificar as propostas adotadas. O Plano foi concluído em 1930 e não implantado, apesar de algumas de suas idéias terem sido apropriadas em intervenções posteriormente realizadas na cidade.

Na concepção desses trabalhos, o urbanismo é visto como instrumento de transformação da cidade, baseando-se na idéia de que o conhecimento técnico e científico pode responder, por si só, a necessidade de resolução de problemas urbanos.

\section{O contexto do urbanismo europeu nas primeiras décadas do século $X X$ e alguns reflexos no Brasil}


O urbanismo científico teve seus fundamentos ainda no século XIX, dentro de uma perspectiva de criação de uma disciplina autônoma tendo como objeto principal de estudo a cidade, analisada segundo princípios de racionalidade. Como marco, pode-se identificar os escritos e propostas de Ildefonso Cerda para Barcelona e a intervenção de Paris protagonizada pelo Barão Haussmann. O primeiro teve a intenção de criar uma base científica universal com soluções generalizadas capaz de dar lugar a uma "Teoria Geral da Urbanização", enquanto que o segundo se dirigiu a uma prática ditada pela vontade de regularizar Paris, com uma perspectiva de melhorar as condições de funcionamento da cidade. Ambos deram ênfase aos aspectos de engenharia urbana e de gestão da cidade. O plano de Paris se baseou num sistema de circulação, substituindo o anterior Plano dos Artistas que se detinha no embelezamento da cidade. A obra de Cerda, apesar de precursora, não teve uma grande difusão na época pelas resistências internas do meio profissional e pela própria extensão do texto, escrito numa língua pouco conhecida, o catalão. (SANCHEZ,1999) Outras contribuições importantes como a do biólogo escocês Patrick Geddes, com sua perspectiva evolucionista e o método de planejamento baseado na análise prévia das informações levantadas vieram se integrar aos fundadores da geografia francesa e tiveram continuidade através de Lewis Mumford, seu aluno, desembocando na criação da Associação Americana de Planejamento Regional.

As bases do urbanismo técnico científico estavam lançadas e se difundiram através de medidas tomadas em diferentes países e cidades, extrapolando as esparsas leis que definiam alinhamentos, gabaritos e licenças para construir. No caso da França, o planejamento urbano global foi uma extensão dessas medidas lideradas especialmente por Henry Prost, Marcel Poete, dentre outros, pertencentes à Sociedade Francesa de Arquitetos e Urbanistas, criada em 1912. (CHOAY, 1988)

A aprovação da lei Cornudet ${ }^{1}$, em 1919, exigindo a realização de projetos de melhoramento, embelezamento e extensão em cidades importantes ou com taxas de crescimento elevadas, num prazo de três anos, obrigou a formação desse profissional em curto prazo visando atender aquela nova demanda. Neste contexto, no mesmo ano foi criada a Ėcole des Hautes Etudes Urbaines, que capacitaria o pessoal técnico destinado às municipalidades. A formulação do curso atendia uma demanda imediata,

\footnotetext{
${ }^{1}$ A Lei Cornudet foi a primeira lei francesa sobre desenvolvimento, embelezamento e extensão das cidades.
}

URBANA, V.5, no 7, out.2013 - Dossiê: Urbanistas e Urbanismo: a escrita da história... - CIEC/UNICAMP 
através de cursos rápidos para o pessoal administrativo e cursos de dois anos para a formação de urbanistas. Os cursos, que a princípio eram destinados exclusivamente a franceses, quatro anos depois já começavam a receber profissionais estrangeiros, cujo número aumentou progressivamente até chegar ao patamar de $50 \%$ dos inscritos. A importância que tomou fez com que se integrasse à Universidade de Paris com a denominação de Instituto de Urbanismo (Institut d'Úrbanisme de I'Université de Paris - IUUP) já em 1924, no mesmo ano da reformulação da lei Cornudet, que reafirmou a necessidade de planos trazendo algumas novidades, como a estrutura de representação das comissões propostas para as cidades. O IUUP passou a constituir um importante centro de formação para franceses, e também para estrangeiros cujos países não tinham tradição de formação nesta área de conhecimento. O Instituto foi responsável por introduzir questões de traçado e da forma urbana, apesar de ter uma abordagem multidisciplinar e científica. O que se constatou foi uma maior dominância relativa de arquitetos deslocando um pouco o eixo predominante dos engenheiros da Ėcole de Ponts et Chaussées nas intervenções nas cidades. O higienismo e o sanitarismo dominantes deram um pouco de espaço à Composição Urbana.

No Brasil, o ensino de urbanismo era incipiente e ministrado nas Escolas Politécnicas, nos Cursos de Formação de Engenheiros e atrelado à cadeira de Saneamento. Excetuando-se os projetos de inspiração Haussmaniana, como a Avenida Rio Branco do Rio de Janeiro ou as obras e realizações de engenharia sanitária (as Avenidas canais de Saturnino de Brito, por exemplo), as intervenções urbanas geralmente não eram precedidas de planos globais e nem o urbanismo fazia parte da formação profissional do Arquiteto.

A contratação de Alfred Agache pelo prefeito para a realização do Projeto de Extensão, Remodelação e Embelezamento do Rio de Janeiro, em 1927, coincidiu com a premiação de viagem de estudo à França dada ao diplomado em Arquitetura pela Escola Nacional de Belas Artes, Attilio Correa Lima, que se fixou em Paris para cursar o IUUP. $\mathrm{O}$ arquiteto passou a viver neste ambiente efervescente, tendo ainda a possibilidade de trabalhar com Agache no plano do Rio em Paris, e ser aluno de renomados profissionais que eram professores do IUUP, tendo sido orientado por Henry Prost para a elaboração de sua tese de doutoramento "Avant-Projet d'aménagement et d'extensione de la ville de Niterói". Esta tese pode ser analisada como a expressão mais acabada dos princípios norteadores do urbanismo do IUUP, especialmente porque não estava comprometida com uma efetiva implantação. O arquiteto retornou ao Brasil em 1931, após a defesa URBANA, V.5, no 7, out.2013 - Dossiê: Urbanistas e Urbanismo: a escrita da história... - CIEC/UNICAMP 
em sessão pública em 1930. A tese foi publicada no órgão oficial do Instituto "La Vie Urbane" (n 8 e 9 de 1932), com prefácio de Henri Prost.

"L'aménagement et l'extension de Niterói constituent en réalité une véritable extension de Rio-de-Janeiro, conçue dans I'espirit des plans régionaux français, dont le développement des agglomérations modernes nécessite la préparation attentive en vie de favoriser la répartition des pleuplements dans les meilleures conditions d'higyène morale et physique, en accord avec les nécessités économiques, bases essencielles de toute oeuvre d'urbanisme". (PROST, 1932)

O curso em Paris deve ter introduzido o arquiteto na trato com as questões do urbanismo, considerando que o tema não fazia parte do currículo de Arquitetura da Escola de Belas Artes do Rio de Janeiro. No seu tempo de estudante, o ensino estava sendo criticado pelo seu caráter pouco inovador, o que fez eclodir greves e a crise de 1930, cujo ápice foi a entrada meteórica do Arquiteto Lúcio Costa na direção da Escola. De volta, Attilio teve uma passagem como professor introduzindo a disciplina de Urbanismo, mas foi preterido no Concurso realizado, deixando a Escola tempos depois. A sua influencia no domínio do urbanismo esteve também expressa nos inúmeros planos que elaborou para o governo em diversas cidades do Brasil. Um acidente aéreo, no Rio de Janeiro, em 1943, interrompeu sua trajetória profissional e apagou muitos vestígios de sua participação no urbanismo brasileiro².

A tese sobre Niterói é raramente encontrada ${ }^{3}$, e sempre foi citada como um documento teórico sem nenhuma repercussão nos caminhos que a Cidade tomou posteriormente. Foi reconhecida como especulação acadêmica em seu intróito: "/e Projet de M. A. Correa Lima n'a pas étè préparé en vie d'une réalisation intrègrale, c'est une conception idèale terminant brillamment d'excellentes études." (idem, 1932)

Analisando-a com mais cuidado, verificou-se que algumas de suas propostas foram incorporadas à cidade algumas décadas depois, ainda que de forma fragmentada

\footnotetext{
${ }^{2}$ Como urbanista Attilio Corrêa Lima realizou o Plano da cidade de Goiânia (1933), o Plano da cidade de Recife (1936), o Plano Regional de Urbanização do Vale do Paraíba e o Plano de Volta Redonda (1941).

${ }^{3}$ Os arquitetos E. de Groer e W. Palanchon para as questões de urbanismo em geral, o engenheiro A. Duffieux para as questões de saneamento, e o engenheiro-arquiteto A. Gladosh para as questões de instalações industriais.
}

URBANA, V.5, no 7, out.2013 - Dossiê: Urbanistas e Urbanismo: a escrita da história... - CIEC/UNICAMP 
e reformulada. Acredita-se na hipótese de que sua proximidade com o governo federal, pela realização do Plano Regional de Urbanização do Vale do Paraíba, compreendendo também o Plano Urbanístico de Volta Redonda, de 1941, permitiu a veiculação e implantação de algumas diretrizes propostas para Niterói, cidade sede do governo do Estado do Rio de Janeiro, considerando-se especialmente os laços familiares entre o ditador Vargas e o Interventor deste estado.

$\mathrm{Na}$ cidade do Rio de Janeiro, a evolução urbana nas três primeiras décadas do século $X X$, se por um lado teve o incentivo do governo federal e do distrito Federal na continuidade do processo de renovação da área central e de embelezamento da zona sul, correspondendo às expectativas das classes dominantes, por outro, sem qualquer apoio do Estado, as indústrias se instalaram na direção dos subúrbios, que se expandiram significativamente nos anos 1910 e 1920 em razão do transporte ferroviário. Nesse contexto, o Plano Agache, após ser aprovado por decreto como Plano Diretor foi mais tarde revogado e substituído por um novo plano, intitulado Plano Geral de Transformação e Extensão da Cidade.

Embora associado à República Velha, o Plano Agache, com suas inúmeras propostas, permaneceu servindo de referência para as intervenções urbanas subsequentes, bem como para a elaboração do pensamento urbano sobre a cidade. A montagem de duas Comissões do Plano da Cidade nos anos 1930 propiciou a formação de um corpo técnico na administração municipal responsável por formular o pensamento urbanístico no Rio de Janeiro; tendo as duas Comissões adotado como referência o Plano Agache, por sua abrangência como plano diretor.

\section{A formação e trajetória de Attilio Correa Lima}

Como era previsível, o filho do escultor José Octavio Correa Lima cursou como aluno livre a Escola Nacional de Belas Artes, onde o pai era professor titular de Escultura e Ornatos. Após essa experiência inicial, no ano seguinte, 1919, inscreveuse no Curso Geral da ENBA, que concluiu em 1922.

Deu continuidade a seus estudos, iniciando o Curso Especial de Arquitetura em 1923. O curso estava se sedimentando por conta de uma reforma curricular e alterações na admissão que começam a ter vigência a partir de 1916. Nesta etapa, entre 1915 e 1924, o número total de alunos nunca ultrapassou a quantia de 20, oscilando o número de ingressantes entre 1 e o máximo de 13, naqueles primeiros 10 URBANA, V.5, no 7, out.2013 - Dossiê: Urbanistas e Urbanismo: a escrita da história... - CIEC/UNICAMP 
anos. Dessa época, alguns nomes ficaram conhecidos, como arquitetos ou como professores, e alguns deles bastantes próximos do jovem Attilio, como os arquitetos Lucas Mayerhofer, Paulo Antunes Ribeiro e Paulo Pires. Na sua vida de estudante de arquitetura sempre se destacava na disciplina Grandes Composições de Arquitetura, na época, de responsabilidade do Professor Archimedes Memória, onde obtinha o primeiro lugar, para finalmente ter sido agraciado com o prêmio "Viagem à Europa", em 1927. O prêmio representou uma inflexão na vida de Attilio, que atingiu uma outra escala como profissional e se direcionou ao urbanismo, área de conhecimento nascente. Ele se estabeleceu em Paris, freqüentando o IUUP.

A vida em Paris como bolsista da ENBA, já recém casado com Olga Lopes Fernandes, foi difícil, num momento em que a Europa vivia o primeiro choque pósguerra, com um custo de vida muito alto, fato remarcado em suas cartas ao pai, então diretor da Escola. A 13 de junho de 1927 chegou a Paris alugando uma mansarda num sétimo andar sem escadas e ali permaneceu com um orçamento apertado e com obrigação de enviar uma aquarela por mês à Escola, fato que tomava seu tempo e o dispersava de seu objetivo principal de estudar urbanismo. Ainda em Paris, nasceu seu único filho Bruno, em 1931.

A permanência de Attilio durante 5 anos na França permitiu-Ihe a proximidade com os expoentes da Escola Francesa de Urbanismo, através dos professores do Instituto, como Henry Prost (seu orientador), Leon Jaussely, Alfred Agache e Jacques Greber. Agache interessou-se pelo aluno carioca e o convidou para estagiar no seu escritório durante a realização do plano para o Rio de Janeiro. Apesar das restrições que fazia ao mestre, considerado pelos pares como ultrapassado, o estágio melhorava suas estritas condições financeiras. Durante sua vida em Paris, dividiu em alguns momentos a moradia com os ganhadores do prêmio-viagem de 1926 e 1927, os arquitetos Lucas Mayerhofer e Paulo Antunes Ribeiro, reiterando a antiga camaradagem da ENBA.

O movimento europeu da arquitetura e do urbanismo era intenso nestes tempos de permanência de Attilio na Europa marcados pela realização dos CIAMs (1928, 1929, 1930), movimento que acompanhou de longe, mas o aproximou das idéias dos profissionais alemães, especialmente do arquiteto Ernest May. Como delegado do Brasil, esteve presente no Congrés International de l'Habitation et de L'Aménagement des Villes, realizado em Paris em 1928, onde compareceram outros nomes importantes como Raymond Unwin, Marcel Poéte e Henry Prost. URBANA, V.5, no 7, out.2013 - Dossiê: Urbanistas e Urbanismo: a escrita da história... - CIEC/UNICAMP 
O arquiteto buscou uma formação complementar freqüentando o curso do Institut de Techiniques Sanitaire du Conservatoire National de Arts et Metiers de Paris, em 1929, formando-se em Técnico Sanitário.

A sua tese pôde ser analisada como a expressão mais acabada dos princípios norteadores do urbanismo do IUUP, especialmente porque não esteva comprometida com uma efetiva implantação. O arquiteto retornou ao Brasil em 1931, após a defesa em sessão pública em 1930, como citado anteriormente, publicada no órgão oficial do Instituto "La Vie Urbane" e em livro com prefácio de Henri Prost. (Figura 01)

A tese - Avant Projet d'aménagement et extension de de la ville de Niterói au Brésil - foi a inscrição de sua proposta utópica na estrutura da cidade.

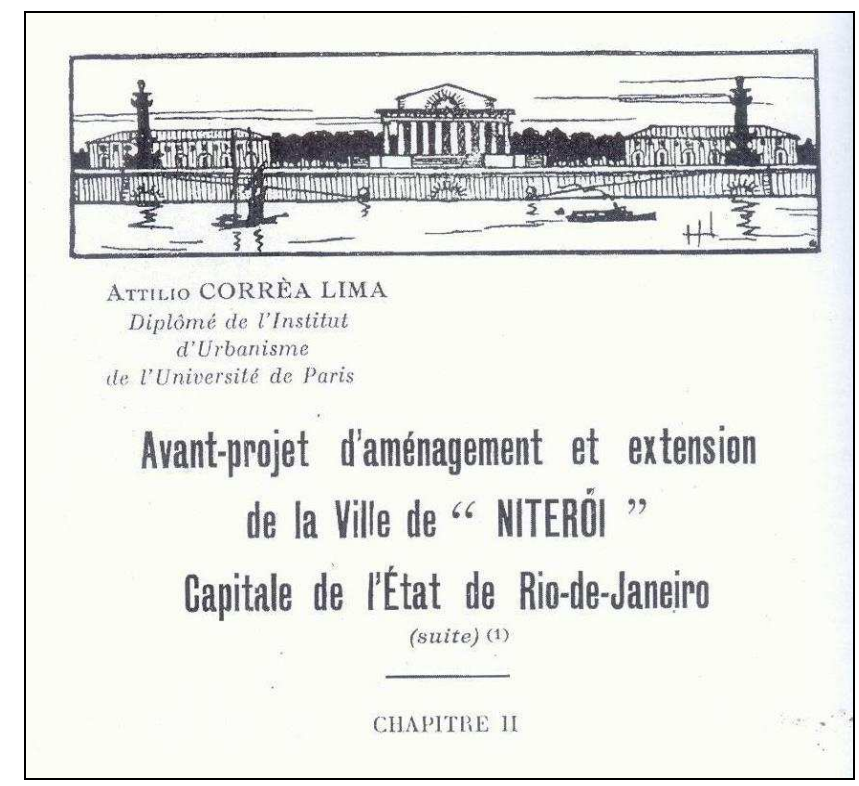

Figura 01: Folha de rosto da revista La Vie Urbaine do IUUP, 1932.

Fonte: Acervo Bruno Corrêa Lima. In: ACKEL, 2007

A tese foi desenvolvida em duas partes: a primeira, sob a forma de diagnóstico, apresentou três capítulos: A Terra, O Homem e a Cidade; a segunda considerou Niterói como extensão do Rio de Janeiro e defendeu a comunicação entre duas cidades por um sistema contínuo. Ponte ou Túnel? As duas possibilidades foram estudadas no segundo capítulo. No terceiro, propôs o Zoneamento; no seguinte, regras de parcelamento; finalmente tratou com grande ênfase os Transportes e fez menção ao esgoto, à água e a inundações.

Nos temas tratados, nos títulos usados e no desdobramento de cada um deles dá para perceber que o cerne da questão era a ligação com o Rio de Janeiro. A trama URBANA, V.5, no 7, out.2013 - Dossiê: Urbanistas e Urbanismo: a escrita da história... - CIEC/UNICAMP 
viária e o sistema de transporte seriam decorrentes dessa ligação. A renovação da área central, com a criação do Centro Cívico e do Centro Comercial, e a expansão de novas áreas, como o Centro Universitário e a Cidade Jardim de Piratininga, constituíam algumas das principais intervenções físicas.

O documento é rico em conceitos e proposições "utópicas", uma vez que os princípios urbanos preconizados no IUUP dificilmente poderiam se adaptar ao traçado urbano já existente na cidade. Entretanto, a liberdade permitida pela elaboração da tese possibilitou especulações sobre a reestruturação da cidade, segundo cânones teóricos em debate na Europa na década de 1920 e deu ao Urbanista o instrumental para os seus futuros planos, como o da cidade de Goiânia e o polêmico Plano da cidade de Recife, além da citada "cidade industrial de Volta Redonda".

\section{A cidade vista pelo plano}

Em primeiro lugar, o autor fez um levantamento das condições da cidade, começando pelo capítulo "A Terra", onde enumerou as principais características de Niterói e a situou geograficamente em relação ao Brasil, à capital do país a ao Estado do Rio de Janeiro. Como era comum na representação da cidade de Niterói em mapas até os anos de 1980, a cidade do Rio de Janeiro era o norte da cidade, como se constata, questão simbólica e real, na foto aérea representada pela Figura 02.

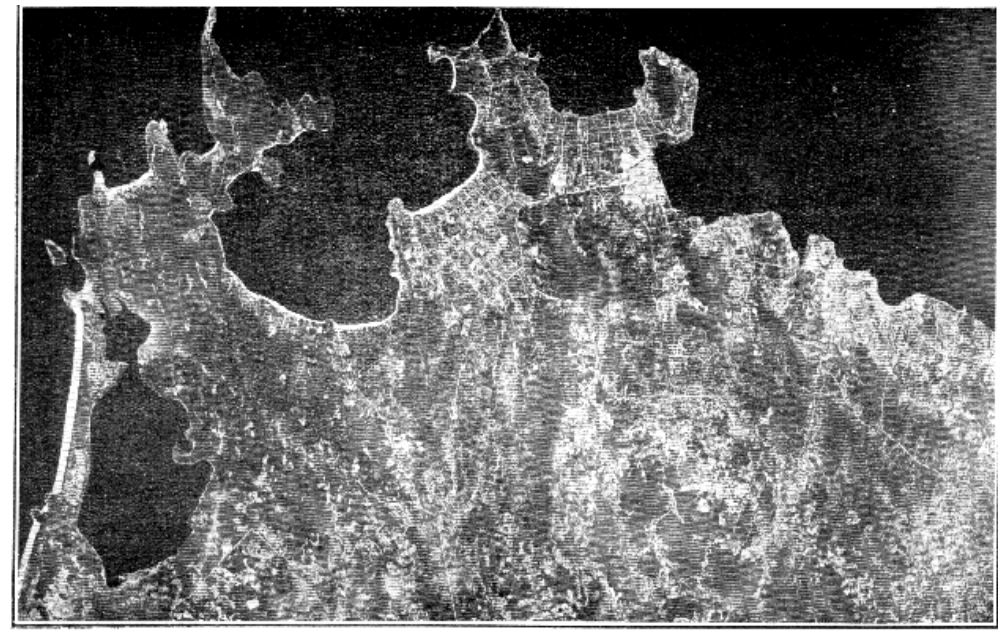

Fig. I - EIAT ACTUEL DE LA VILLE

Asacmblage des photos aćriennes da "Serviee géogiaphique militairess" hrésilien montrant la project
tale de la villes.

Figura 02: Situação da cidade, fotos aéreas, Seviço Geográfico do Exército. Fonte: LIMA, 1932. 
No capítulo seguinte, "Homem", forneceu dados sobre o crescimento populacional e as condições sanitárias, justificando a curva ascendente da população, cujo maior incremento se verificara no final dessa década de 1920. Fez especial referência às condições de saúde publica utilizando o conceito de "Index Vital" de Pearl, considerando-o favorável, salvo nos anos das epidemias de varíola (1905, 1908 e 1922) e de gripe "espanhola" (1918). Assinalou também os índices estáveis e elevados de tuberculose.

Niterói tinha pouco mais de 100.000 habitantes, estava vivendo um processo de incremento populacional significativo e apresentava uma superfície reduzida (56 $\mathrm{km}^{2}$ ), por conta do desmembramento de sua área para o vizinho município de São Gonçalo.

O autor colocou em destaque sua simetria topográfica com o Rio de Janeiro, em que as cadeias montanhosas, lagoas e recorte da costa reproduziam a cidade vizinha, resultado da formação geológica da Baía de Guanabara.

No capítulo seguinte, "Cidade", tratou de sua origem e evolução, mostrando as diversas etapas do seu povoamento e ocupação. (Figura 03)

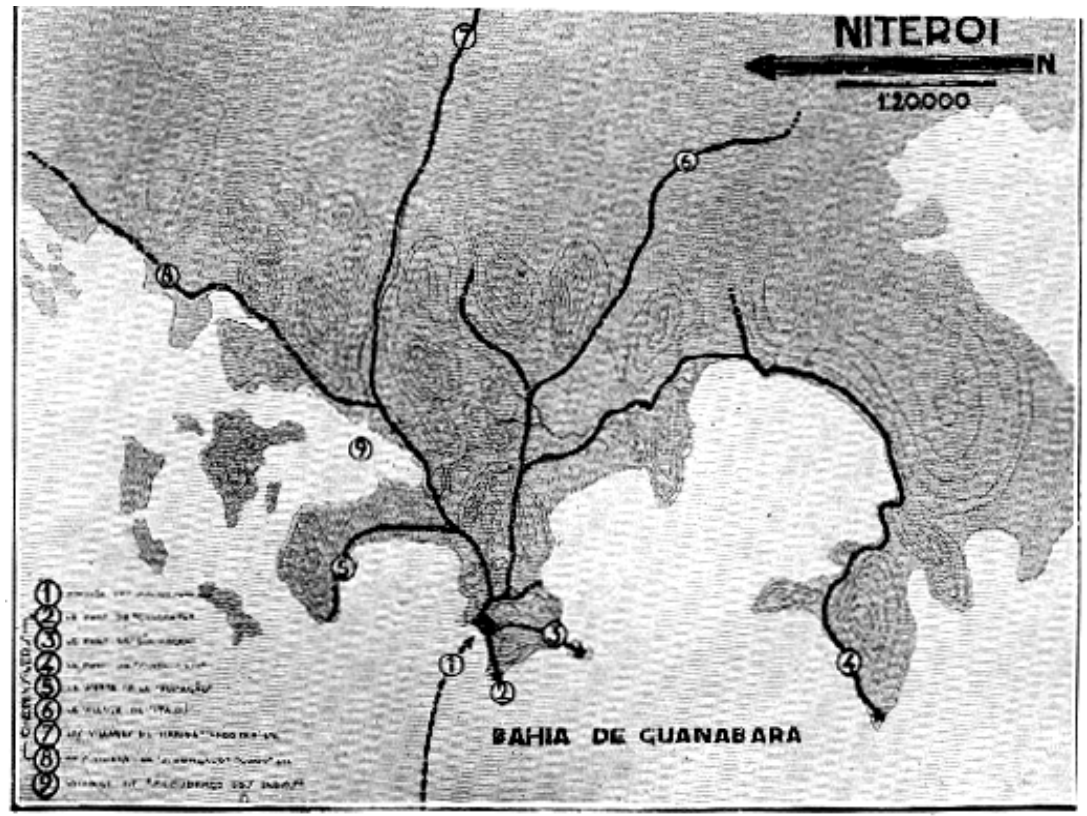

Fig. 6 - L'O!RICIINE DE LA VII.LE

de communications, eneare existantes anjnurdiliti.

Figura 03: A origem da cidade.

Fonte: LIMA, 1932.

URBANA, V.5, n 7, out.2013 - Dossiê: Urbanistas e Urbanismo: a escrita da história... - CIEC/UNICAMP 
Como se constata na Figura, os números representam a chegada da cidade (1), os portos (2, 3 e 4), a Ponta da Armação, onde se desenvolveu a indústria do Barão de Mauá na $2^{a}$ metade do século XIX, os núcleos de Itaipu (6), Maricá e Cabo Rio (7), São Gonçalo (8) e São Lourenço dos Índios (9).

Nessa imagem, fica configurada a perda de importância do núcleo fundador da cidade, que corresponde ao número (9). O mapa aponta como ponto de chegada do colonizador o número (1), que marca a fase da cidade do Rio de Janeiro como capital do reino e a implantação da Vila Real da Praia Grande pelo Rei D. João VI. O início do século XX não enfatizou a Aldeia Indígena de São Lourenço dos Índios, que se deu no século XVI (1573), como marco inicial de criação da cidade.

Na caracterização, o Plano deu ênfase a dois aspectos. O primeiro referiu-se à preocupação higienista, mostrando a estatística sanitária das doenças endêmicas, o coeficiente de mortalidade e natalidade, ainda que essa questão se rebatesse de forma genérica nas propostas. Parece que constituiu uma obrigatoriedade metodológica, remanescente das relações estreitas entre higienismo e urbanismo. 0 segundo, já representou uma convicção do autor, no qual ele retomou, em diversos momentos do trabalho - a importância da ligação com o Rio de Janeiro - "la ville ne se développe qu'em tant que le service de transport s'améliore."

Numa análise, fez considerações sobre as condições topográficas da cidade e justificou a implantação na topografia plana em torno de uma grande área, o "Campo de Sta. Helena" (na realidade Campo de Dona Helena). (Figura 04) 


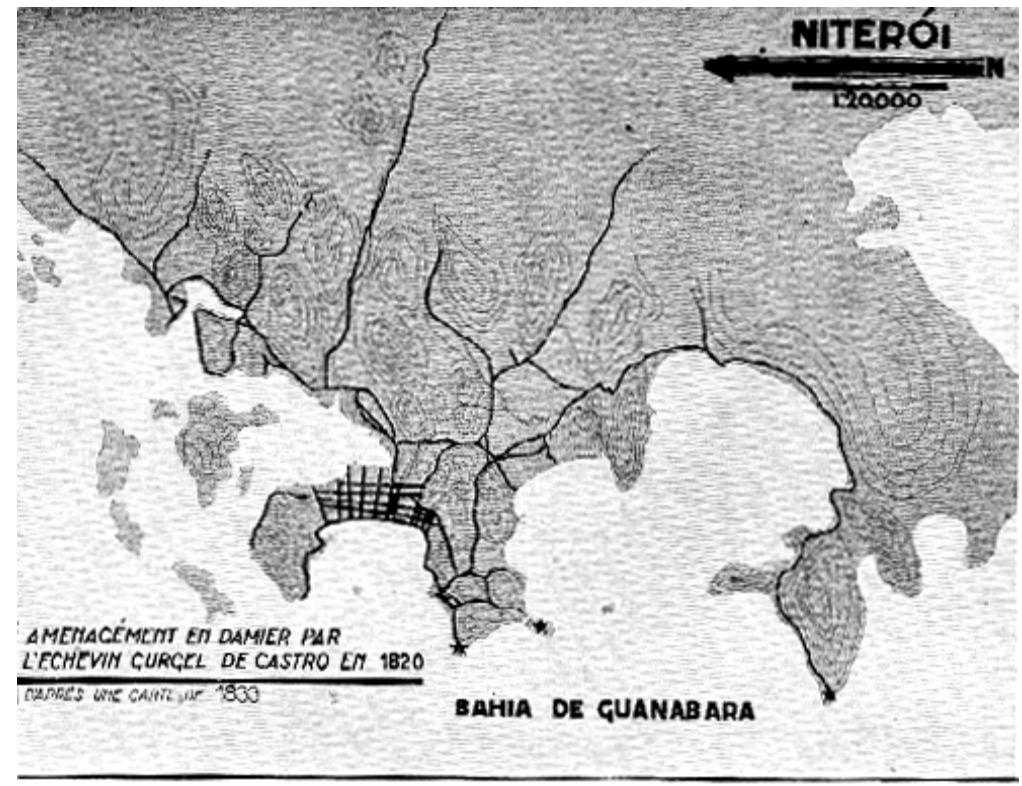

Fig. 7 - LA VILIE D'APRÉS UNE CARTE 1833

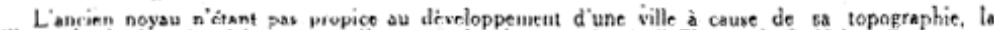
ille se foude dans la plnine autour d'une grando place uppelée le "Champ de St-Helens"

Figura 04: A cidade segundo um plano. Fonte: LIMA, 1932.

\section{"Ce qu'on propose de faire"}

Nessa segunda parte da tese, o autor indicou o enunciado de propostas baseado na convicção de que Niterói era uma extensão do Rio de Janeiro e como tal seria importante implantar um sistema de transporte contínuo entre as duas cidades.

Túnel ou Ponte?

Essa questão primordial deveria ser respondida e as duas primeiras hipóteses foram cuidadosamente estudadas, baseadas em experiências já realizadas no estrangeiro, especialmente o túnel New York - New Jersey e a ponte sobre o Hudson, também em Nova York. A discussão tecnológica ganhou relevo, e sem chegar a optar por uma das alternativas, o trecho mais estreito para vencer a baía, ponta do Calabouço no Rio e ponta do Gragoatá em Niterói, foi escolhido como local mais adequado para acesso da ligação entre as duas cidades. (Figura 05) 

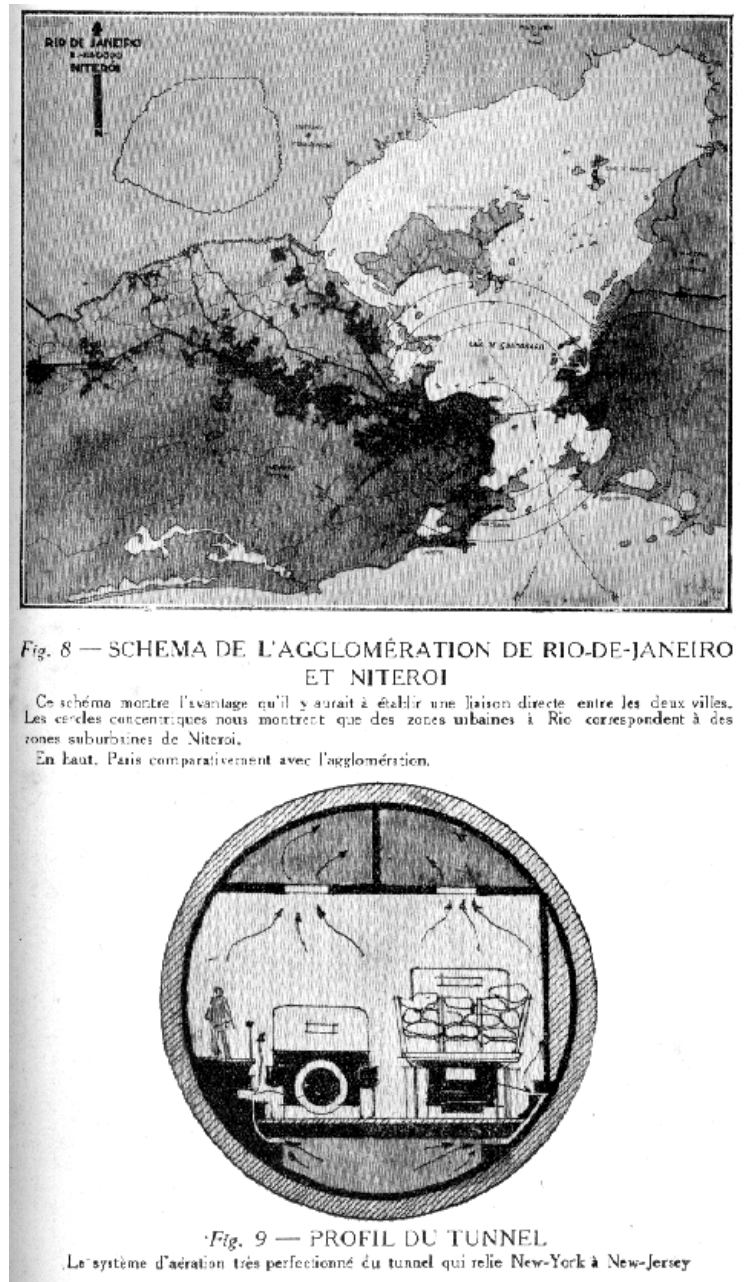

Figura 05: Esquema da Aglomeração do Rio e Niterói. Fonte: LIMA, 1932.

O esquema mostrou as vantagens resultantes de uma ligação direta entre as duas cidades. Os círculos concêntricos mostraram a diferença de escalas entre as cidades, onde as zonas urbanas do Rio correspondiam às zonas suburbanas de Niterói.

O autor elencou vantagens, preços e exequibilidade das duas propostas ponte ou túnel, e deixou a decisão em aberto, mas deslocou a ligação existente através das barcas para a esquerda, aproximando-a do Bairro de São Domingos.

O projeto previu a realização de novos aterros por nivelamento de quatro morros existentes na área central (o futuro aterro da Praia Grande) e criou um centro de "irradiação", em terrenos recuperados pelo arrasamento desses morros. 


\section{A Formação e trajetória profissional de Alfred Agache}

Em 1905, formou-se em arquitetura na Ecole dês Beaux-Arts de Paris, realizando em seguida o curso de sociologia no Collège Libre dês Sciences Sociales, também na capital francesa.

Em 1909, passou a colaborar ativamente com o Musée Social de Paris, entidade de direito privado criada por profissionais liberais, políticos, universitários e representantes da burguesia industrial francesa, que advogavam um programa de reformas para a solução da chamada questão social. Dois anos depois, em 1911, participou da fundação da Société Française dês Urbanistes - SFU, atuando como secretário-executivo da instituição por mais de duas décadas. Conquistou a medalha de ouro no concurso internacional de projetos para a construção de Canberra, nova capital da Austrália. Entre 1912 e 1913, elaborou os Planos de Remodelação Urbana das cidades de Dunquerque, na França, e Casablanca, no Marrocos. Em 1914, participou da Exposição Internacional Urbana de Lyon, na França, e em 1916 publicou o livro "Como Reconstruir nossas Cidades Destruídas", em parceria com Jacques-Marcel Auburtin e Edouard Redont. Entre 1925 e 1926, executou projetos urbanísticos para as cidades francesas de Creil e Poitiers.

Em 1927, foi contratado pelo prefeito do Rio de Janeiro para elaborar o Plano Urbanístico da cidade. Chegando ao Rio, proferiu algumas conferências e entre 1928 e 1930 elaborou o Projeto de Remodelação do Rio de Janeiro, conhecido como Plano Agache, propondo importantes mudanças como o zoneamento e a construção de um sistema de vias expressas para melhorar a circulação da cidade. Para a área central da então capital federal projetou um grande boulevard conectando a Praça da Bandeira com o porto e cruzando a área mais densa do centro. Com a Revolução de 1930 e a mudança do poder no país, a execução de seu plano foi postergada.

Em 1930, projetou o ajardinamento do Parque Farroupilha, em Porto Alegre, à semelhança dos jardins franceses. Retornou à França e publicou o livro "Cidade do Rio de Janeiro: extensão, remodelação, embelezamento" (AGACHE, 1930). Em 1938, organizou a Exposição do Progresso Social, realizada em Lille, França. Em 1939, participou da Exposição do Progresso da Ciência, em Lille.

No mesmo ano, regressou ao Rio de Janeiro, passando a trabalhar como consultor da empresa de engenharia Coimbra Bueno \& Cia Ltda. Entre 1940 e 1943, foi um dos principais responsáveis pelo Plano de Urbanização da cidade de Curitiba, URBANA, V.5, n 7, out.2013 - Dossiê: Urbanistas e Urbanismo: a escrita da história... - CIEC/UNICAMP 
encomendado pelo prefeito Rozaldo de Mello Leitão à firma Coimbra Bueno. Algumas proposições do plano para a capital paranaense foram implementadas, notadamente a abertura de extensas avenidas, a construção de galerias pluviais e a implantação do centro cívico, reunindo os principais edifícios administrativos do governo estadual.

Em 1942, suas propostas para reurbanização do Rio de Janeiro foram retomadas pelo prefeito Henrique Dodsworth e adaptadas às novas condições da cidade por uma comissão formada por Lucio Costa e Affonso Eduardo Reidy, entre outros arquitetos e urbanistas.

Também elaborou projetos urbanísticos para São Paulo, Vitória e Recife, e cidades de outros países, como São Petersburgo, Chicago, Lisboa e Istambul. No decorrer de sua carreira, atuou ainda como professor do Instituto de Urbanismo da Universidade de Paris.

\section{O Plano para a cidade do Rio de Janeiro}

A necessidade de confecção de um plano para a cidade foi reconhecida pela emergência da temática do urbanismo em congressos, jornais e revistas, bem como na experiência de várias cidades do mundo, que adotaram o urbanismo como solução para seus problemas. Diante de uma conjuntura econômica favorável, o então prefeito da cidade do Rio de Janeiro, Distrito Federal, Antônio Prado Junior, buscou subsídios técnicos para o ordenamento do crescimento urbano. Para tanto, solicitou a contratação de levantamento aerofotogramétrico do Distrito Federal, necessário à atualização da carta cadastral datada de 1893. Nesse momento, "por meio de mensagem de 30 de agosto de 1927, ao Legislativo Municipal, e por iniciativa do Rotary Club", Prado Júnior requereu autorização para abrir os créditos a serem destinados à elaboração de um plano urbanístico para a cidade do Rio de Janeiro. (OLIVEIRA, 2009, p. 26) Sua formulação foi entregue ao urbanista francês Alfred Hubert Donat Agache, gerando polêmica nos meios técnicos locais quanto à escolha de um profissional estrangeiro.

Segundo Abreu (ABREU, 1981, p.86), a iniciativa de elaboração de um plano ideal para a capital do país constituiu "o exemplo mais importante da tentativa das classes dominantes da República Velha de controlar o desenvolvimento da forma urbana carioca, já por demais contraditória". 
A administração de Prado Júnior, ao retomar os serviços de desmonte do Morro do Castelo, ampliou a área disponível da esplanada, com o arruamento seguindo as orientações do Plano Agache, cuja proposta começou a ser delineada com a execução dos Projetos de Alinhamento 1.791 e 1.805, aprovados em 1928, e que deu início à pavimentação de ruas, à venda de lotes em área pública e à construção de algumas edificações. (OLIVEIRA, 2009, p.27) (Figura 06)

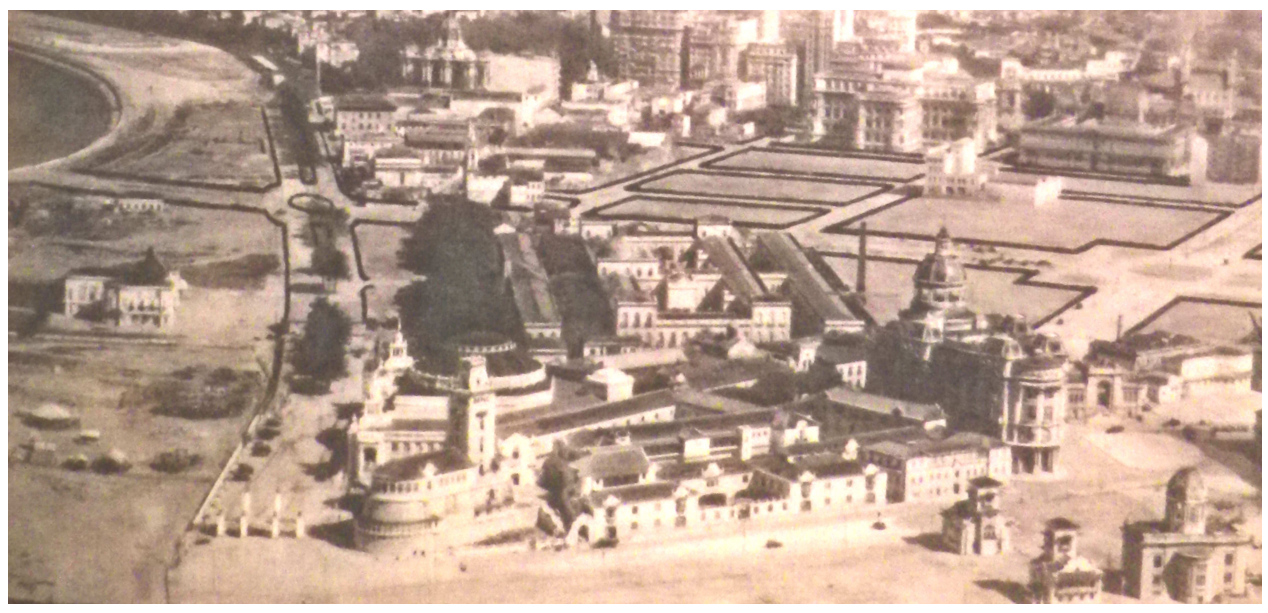

Fig. 06: Esplanada do Castelo, com o arruamento em execução. Fonte: AGACHE, 1930.

O escopo dos serviços contratados foi "um plano regulador destinado a fixar o traçado e o dimensionamento de vias públicas e altura das edificações, criando praças, jardins públicos e espaços livres diversos, bem como sítios destinados à monumentos, edifícios e serviços públicos". E, além disso, abrangia "previsões acerca da distribuição de água potável, rede de esgotos e saneamento do solo". (Idem, p. 28)

\section{A montagem do Plano}

Em 1927, Alfred Agache foi convidado a realizar uma série de conferências sobre o desenvolvimento e remodelação das cidades. O objetivo dessas conferências era informar o grande público "o programa do urbanismo e como devia ser especialmente considerado na capital do Brasil" (AGACHE, 1930, p. 3). Seus produtos seriam a introdução de um relatório que justificaria aos cariocas a necessidade e o interesse num programa geral de remodelação, dentro do qual seria elaborada uma "Planta Directriz de Extensão, de Remodelação e de Embellezamentos". Foram 
organizadas cinco conferências, cujos temas eram: 1) O que é o Urbanismo; 2) Como se elabora o Plano de uma Cidade; 3) Cidades-Jardins e Favelas; 4) a Fotografia Aérea e a Planta das Cidades; 5) Ensino e Propaganda do Urbanismo em França. No relatório que resultou das conferências, Agache apresenta uma síntese do significado de cada tema, um sumário do que observou no Rio de Janeiro e os fins visados por ele. (Figura 07)

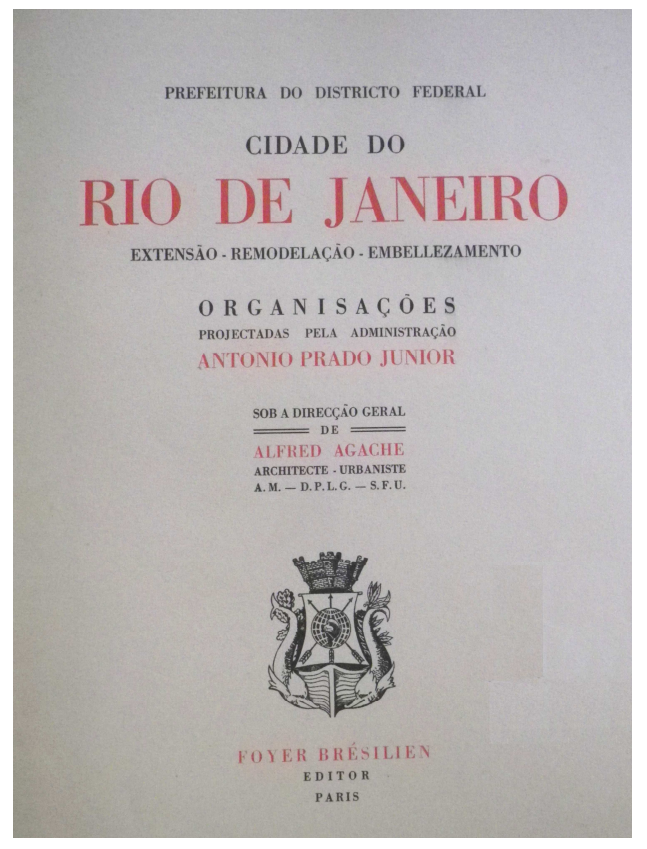

Figura 07: Contra-capa do Plano de Extensão, Remodelação, Embelezamento da cidade do Rio de Janeiro. Fonte: AGACHE, 1930.

Uma corrente de pensamento contrária à contratação de Agache encarava o urbanismo como um assunto técnico a ser tratado no âmbito estrito da Prefeitura, visão esta compartilhada por vários segmentos, incluindo o Instituto de Arquitetos do Brasil e o Instituto Central dos Arquitetos, que consideravam inoportuna a contratação de um estrangeiro. (OLIVEIRA, 2009, p.27)

Em meio à polêmica acerca de sua contratação, Agache montou um escritório no primeiro andar do Theatro Municipal para o início de seus trabalhos. Sua equipe incluía engenheiros, sanitaristas, geógrafos, geólogos e arquitetos ${ }^{4}$. Figuraram como

\footnotetext{
${ }^{4}$ A publicação da tese de Attílio Correa Lima consultada pertence ao Dr. Miguel Pereira, membro do Conselho de Preservação de Niterói.
} 
colaboradores brasileiros os arquitetos D. Albuquerque, Affonso Eduardo Reidy, Santos Maya, Attílio Correa Lima, M. Barroso e H. Pelagion.

Com relação à estrutura, o Plano Agache apresentou na parte introdutória uma abordagem do arquiteto sobre seu entendimento do Urbanismo como conjunto de regras aplicadas ao melhoramento da edificação, do arruamento, da circulação e do descongestionamento das artérias públicas. "(...) é a remodelação, a extensão e o embellezamento de uma cidade levados a effeito mediante um estudo methodico da geographia humana e da topographia urbana sem descurar as soluções financeiras" ( $A G A C H E$, 1930, p. 4). Também apontou sobre a cidade do Rio de Janeiro, a necessidade de uma intervenção urbanística devido ao que ele acusou como "mórbidas manifestações de um crescimento não previsto". (AGACHE, 1930, p. 5). Em síntese, a partir dos temas propostos nas conferências, nesta primeira parte do Plano, Agache tratou a situação urbana do Rio de Janeiro, quando sua história e evolução foram analisadas desde a fundação até a situação urbana daquele momento.

A segunda parte do Plano tratou dos princípios que norteavam o plano diretor, a estrutura viária e transportes, assim como o uso do solo, segundo o que ele chamou de "elementos funcionais".

Já a terceira parte foi dedicada ao estudo dos problemas sanitários, com diagnósticos e propostas voltadas para o equacionamento dos problemas relativos ao abastecimento de água às inundações e ao escoamento das águas pluviais, ao saneamento urbano e à limpeza pública em termos gerais.

\section{A cidade vista pelo plano}

A cidade foi abordada de forma global, embora o foco tenha sido a área central. O plano, denominado de remodelação, extensão e embelezamento, voltou-se para os aspectos ligados à estética e ao saneamento. Segundo Rezende (REZENDE, 1999, p. 362), não se propôs a ser um plano de desenvolvimento, mas somente um plano físico-territorial. Também tratou a cidade como um organismo vivo, "essas nascem, crescem, vivem e como os seres animais, enfraquecem e morrem". Nesse sentido, seus órgãos deveriam estar aptos a exercer as funções que lhes eram próprias: circulação, digestão e respiração.

Evidencia-se no Plano a intenção de um ordenamento da cidade, para o qual utilizou o zoneamento e a legislação urbanística. O zoneamento, instrumento de URBANA, V.5, no 7, out.2013 - Dossiê: Urbanistas e Urbanismo: a escrita da história... - CIEC/UNICAMP 
intervenção muito utilizado à época, seria uma tentativa de ordenar a cidade, evitando o caos que se estabeleceria, segundo Agache, caso o crescimento da cidade não fosse controlado.

Os problemas habitacionais seriam resolvidos com diferentes tipologias habitacionais e uma política de planejamento territorial bem conduzida. Para as favelas, a solução proposta foi a construção de habitações a baixos preços, em alguns casos totalmente subvencionadas pelo estado. Apesar da abordagem superficial do tema habitação, o saneamento foi tratado com a profundidade técnica esperada. Para os problemas relacionados ao saneamento, como água, esgoto e drenagem, a cidade foi tratada como um todo, embora não tenha determinado as áreas onde ocorreriam as principais obras de saneamento.

Da mesma forma que o saneamento, o sistema viário também tratou a cidade em sua totalidade, no sentido de aumentar a sua eficiência ainda que muitas das propostas atendessem também um aspecto estético. Os valores de funcionalidade e embelezamento foram, então, associados. De acordo com Rezende (REZENDE, 1999, p. 364), o sistema viário foi tratado como a ossatura do Plano Diretor; dentro de uma visão orgânica da cidade, constituiu uma das funções principais: a circulação. (Figura 08)

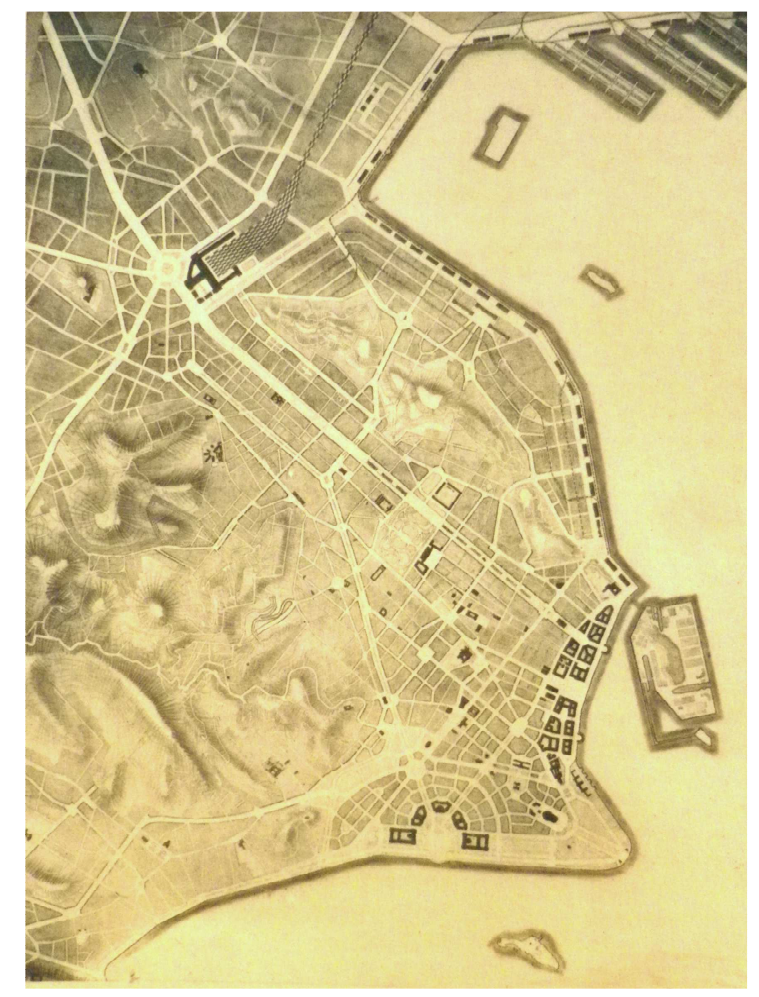


Figura 08: Praças e rótulas nos bairros centrais da cidade.

Fonte: AGACHE, 1930.

Sobre o sistema de transporte, Agache vislumbrava um sistema integrado, com a substituição dos bondes, a abertura de novas vias de ligação entre os bairros e de vias arteriais principais de acesso ao centro. Nesse sistema, o transporte ferroviário desempenharia um papel importante, servindo especialmente à zona industrial e aos subúrbios.

Em síntese, a proposta geral foi de reorganização do sistema viário e de transporte existente, melhorando alguns trechos com a criação de outros. Nesse sentido, a remodelação da cidade do Rio de Janeiro para Agache seria dependente, em grande parte, da reorganização dos meios de transporte, com o aperfeiçoamento dos transportes existentes e a implantação de novas redes de transporte rápido, como a rede ferroviária e metropolitana. O Plano apresentou a ligação da cidade do Rio de Janeiro com Niterói, propondo para a mesma a utilização de lanchas e hidroplanos.

\section{Aproximações: Tese de Niterói e Plano Agache do Rio}

A tese cobriu a cidade como um todo e procurou articular através de um sistema de transportes que se complementava ao Rio de Janeiro e aos diversos bairros existentes, propondo a ocupação de uma nova área: o bairro oceânico de Piratininga.

A criação de uma nova entrada da cidade foi estudada em função de duas hipóteses: ponte ou túnel; e outras conexões foram estabelecidas através de novos traçados; um zoneamento também foi proposto. Centros especializados e atividades pertinentes foram previstas dentro de um modelo de planejamento funcionalista. (Figura 09) 


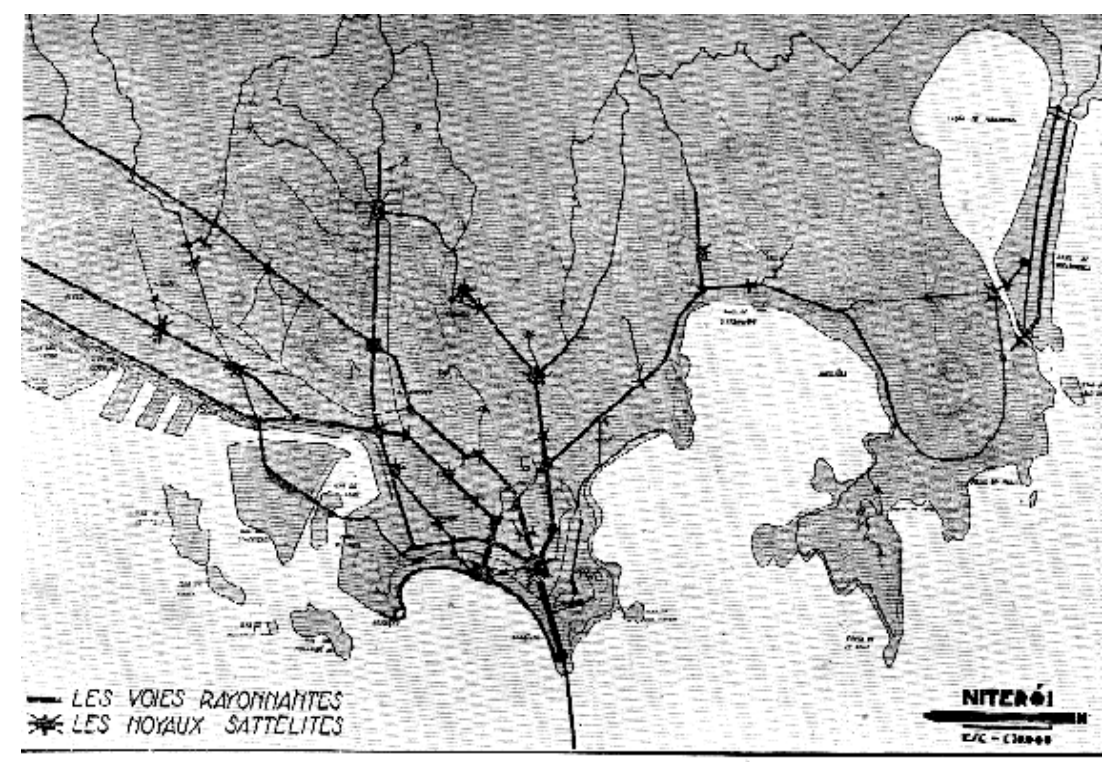

Fig. A3 - LES VOISA RAYONNANTES

Con voica résliant la liaison de tout endroit de la ville ave le centre

Figura 09: As vias radiais.

Fonte: LIMA, 1932.

As vias hierarquizadas e os nós satélites e foram integrados ao centro irradiador localizado no terminal de ligação com o Rio de Janeiro. Este deveria fazer parte do Centro Comercial projetado. O Centro seria constituído de uma grande praça, novo centro comercial de Niterói. Cercado por edifícios de 100 metros de altura, a praça de grandes dimensões (240m X 300m) apresentava um sistema de circulação giratória que distribuia de forma continua o fluxo de carros para os diferentes locais da cidade. Dentre as 8 vias que chegavam à Praça, destacava-se a principal, de 80 metro de largura, com várias pistas e jardins, tendo na borda das principais pistas, palmeiras imperiais, formando uma "via triunfal". Esta via seria o tronco de ligação Niterói - Rio de Janeiro.

Caso a opção fosse o túnel, algumas mudanças seriam necessárias, mas essa praça, de uso comercial, permaneceria conectada por um sistema de artérias aos bairros da zona sul (Icaraí, Cubango, Santa Rosa, São Francisco e Piratininga), a São Gonçalo e Interior do Estado do Rio de Janeiro, assim como com os bairros da zona norte (Barreto, Porto, Ilha da Conceição).

O Centro Cívico, uma praça monumental, teria o seu entorno ocupado pela construção das Secretarias de Estado e do Palácio Presidencial. Constituiria o espaço oficial das grandes comemorações cívicas. Diante dele, no cruzamento das vias, um URBANA, V.5, no 7, out.2013 - Dossiê: Urbanistas e Urbanismo: a escrita da história... - CIEC/UNICAMP 
grande monumento comemorativo da fundação da cidade e um desembarcadouro de honra para os dias festivos foram projetados. Uma avenida axial de 50 metros de largura ladeada de edifícios públicos ligava o conjunto com a atual praça das barcas (Martim Afonso), alargada e refeita. Diante dessa Praça, um pouco desviada do eixo, a demolição do casario entre duas ruas do Centro (Conceição e José Clemente), possibilitaria a criação de uma avenida tratada com platôs e fontes que chegaria à praça, no eixo principal desse conjunto. A Praça da República seria mantida com uma pequena mudança do largo da Biblioteca, fazendo parte do conjunto cívico. (Figura 10)

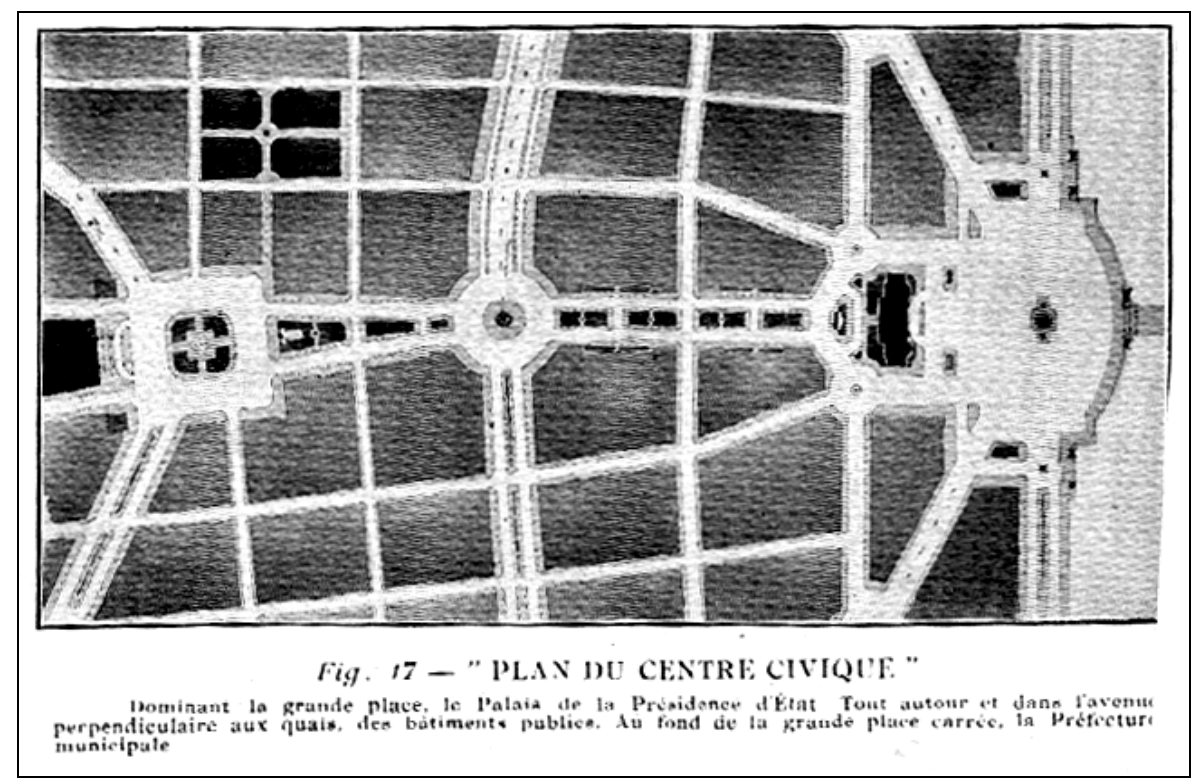

Figura 10: Plano do Centro Cívico: Fonte: LIMA, 1932.

Outro elemento importante da tese foi o zoneamento, que propôs áreas bastante especializadas. O território municipal foi dividido em quatro zonas (comercial, industrial, habitacional e rural), com especificação de legislação de parcelamento, uso e ocupação do solo, gabaritos, orientação solar, afastamento e benefícios fiscais para estimular a utilização proposta. As construções em cada uma dessas zonas teriam seu volume definido, com gabaritos e pés direitos pré-determinados em função da largura das ruas, interditando-se os pátios internos fechados. $\mathrm{Na}$ zona comercial, a verticalização era obrigatória (térreo e 4 pavimentos), com galerias cobertas sobre a via pública. As indústrias deveriam permanecer entre a ponta da Armação e o bairro do Barreto, guardando a tendência já verificada de aproveitar as vantagens de localização (porto e estrada de ferro). O comércio, além do centro comercial, ocuparia áreas satélites - os centros de bairro. Com relação à moradia, o plano estabeleceu zonas de URBANA, V.5, no 7, out.2013 - Dossiê: Urbanistas e Urbanismo: a escrita da história... - CIEC/UNICAMP 
uso exclusivo, em 3 categorias: densas, individuais e populares. O problema das favelas foi citado, sendo proposta a construção de habitações econômicas, individuais, de responsabilidade do Estado. Uma Cidade Operária foi prevista nas encostas do Barreto, com traçado em semi-círculo, dotada de estádio e áreas de lazer, formando um pequeno centro. (Figura 11)

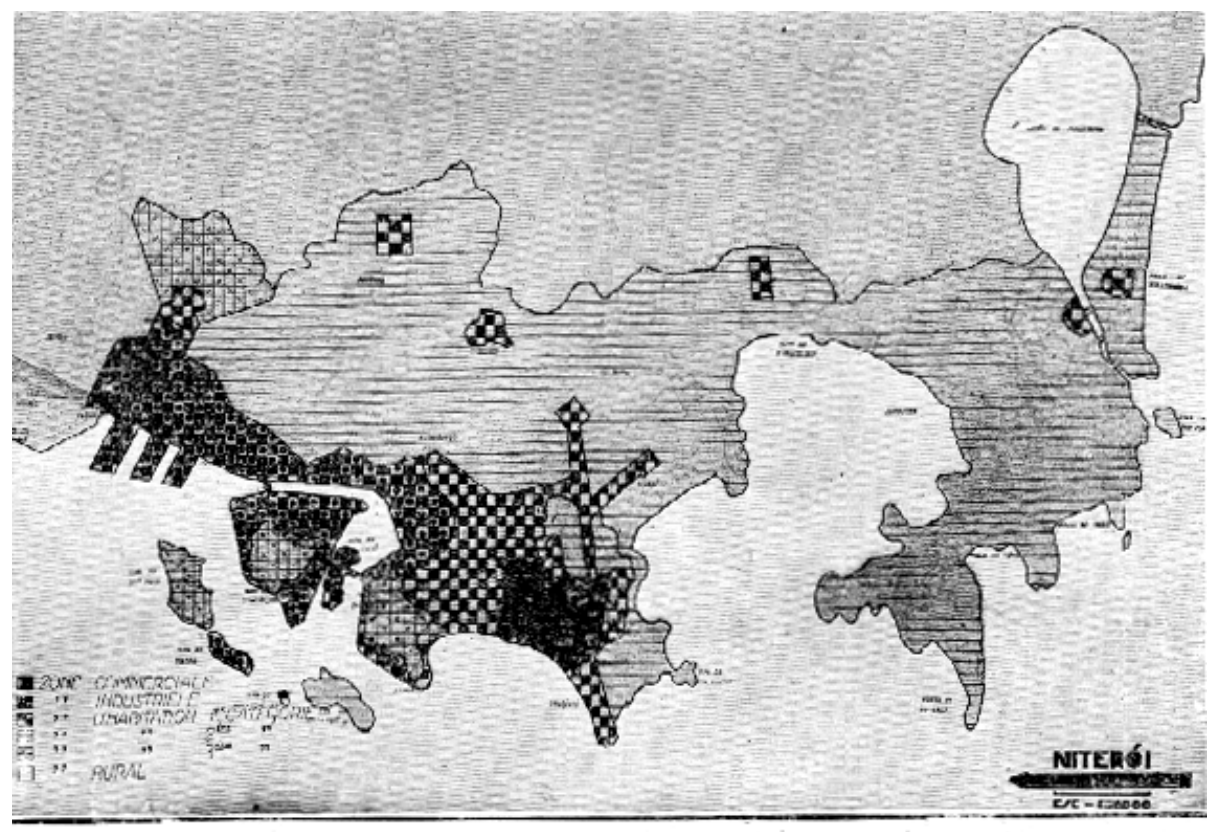

Iig. 22 - ZONING RISI.FMENTÉ

Délimitation obligatoire des difrér.nta quartiers.

Figura 11: Zoneamento em 6 zonas; Zona Comercial, Zona Industrial, Zona Habitacional, 1,2 e 3 e Zona Rural, e Centros Secundários. Fonte: LIMA, 1932.

Também foi proposta uma Cidade Universitária junto ao bairro de Cubango, dotada de prédios para as faculdades, residência universitária e hospital. Junto à praça quadrada, no cruzamento da rua da Universidade com a que levava a Santa Rosa, situava-se na elevação do terreno, o conjunto dos museus.

A cidade-jardim, nos moldes de Howard foi projetada para Piratininga. O acesso difícil poderia ser facilitado pela perfuração de um túnel (preliminarmente, o acesso poderia ser feito por São Francisco, Jurujuba, passando por Imbuí). O traçado proposto para a cidade jardim foi em semi-círculos, combinado com o tradicional xadrez. 0 saneamento da lagoa e o plano de ocupação foram sustentados por sugestões sobre a formação de uma sociedade que receberia financiamento para o empreendimento, pagável em 30 anos. (Figura 12) 


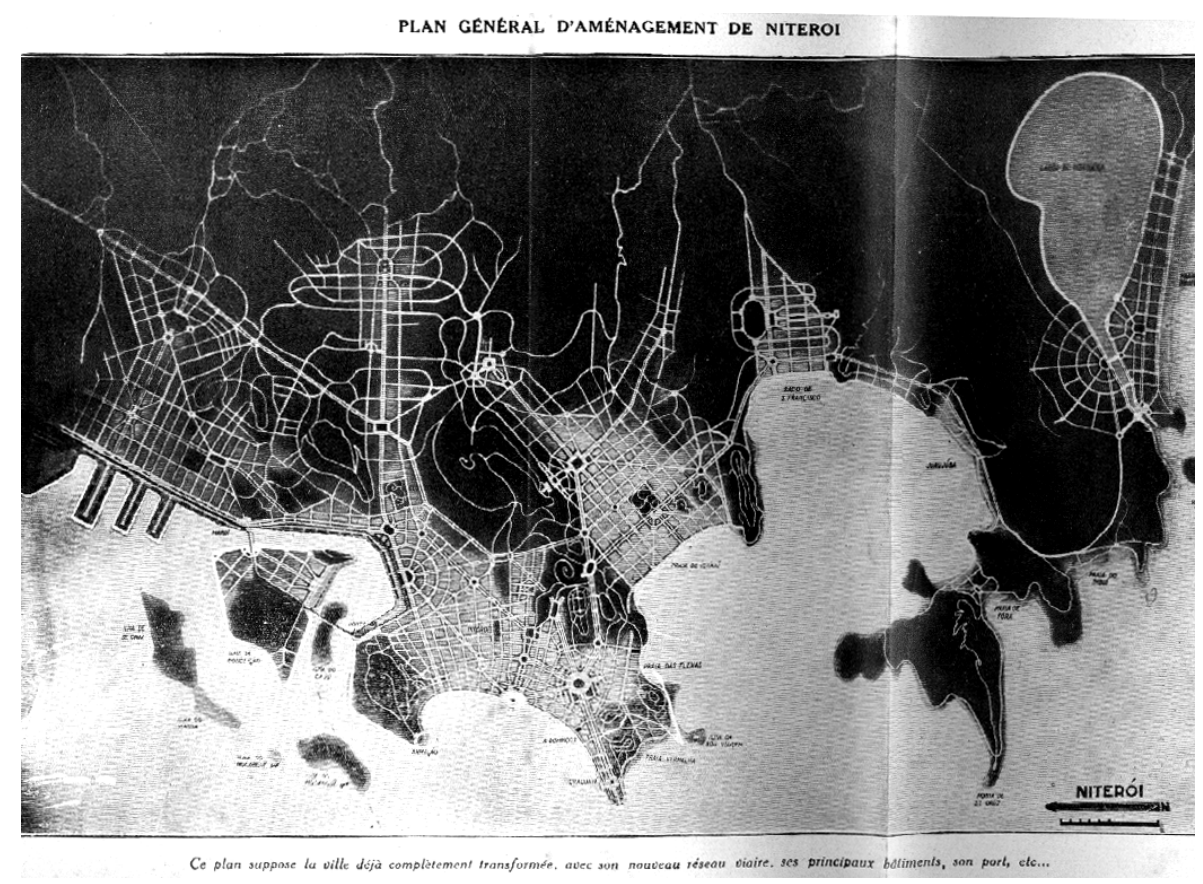

Figura 12: Plano geral de Niterói, incluindo a cidade jardim de Piratininga. Fonte: LIMA, 1932.

As rodovias eram arborizadas, adotando como solução a obrigatoriedade de passagem por Niterói do sistema viário da capital federal para o interior do Estado. As vias urbanas foram hierarquizadas por categorias, principais e secundárias, com definição de dimensão e tratamento de cada uma delas.

O autor se deteve no detalhamento do sistema local de transportes, identificando graficamente a intensidade do então atual sistema de bondes, verificando a sua maior frequência para a zona norte - Barreto e Fonseca. Propôs um sistema baseado na utilização de três meios diferentes de transporte: 5 de metrô, 8 de bondes e 9 de ônibus. O sistema hidroviário, das barcas, passaria a ser um transporte de caráter turístico, perdendo a sua função de transporte de massa.

As redes de abastecimento de água, de esgotos e de drenagem mereceram uma referência especial, apresentando algumas recomendações para sua implantação.

O plano teve algumas diretrizes fundamentais, como a intensificação da ligação com o Rio de Janeiro, criação de centros irradiadores (sistema circular giratório, em torno de praças de grande dimensão), criação de eixos monumentais marcando a entrada da cidade e de centros verticalizados de usos especiais (Comercial e Cívico). (Figura 13)

URBANA, V.5, no 7, out.2013 - Dossiê: Urbanistas e Urbanismo: a escrita da história... - CIEC/UNICAMP 


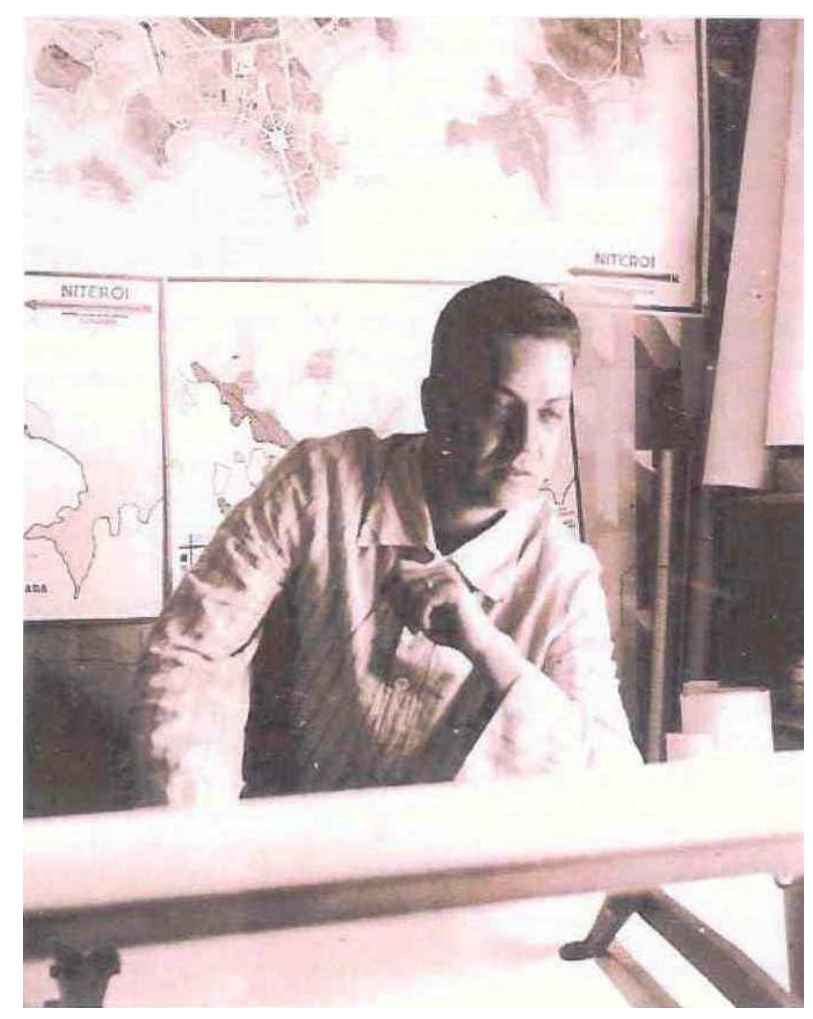

Figura 13: Attilio Correa Lima com o projeto-tese de Niterói ao Fundo. Fonte: Acervo Bruno Corrêa Lima. In: ACKEL, 2007.

O Plano Agache, por sua vez, com visão ampliada da aglomeração urbana e enfoque regional, agregou a cidade de Niterói, assim como as ilhas da Baía de Guanabara e a Serra dos Órgãos. A importância regional do Rio de Janeiro, segundo o Plano, dizia respeito ao escoamento da produção, não só do Distrito Federal, mas também dos Estados do Rio de Janeiro, São Paulo e Minas Gerais. O Plano estabeleceu linhas de transporte rápido, que inclusive deveriam se estender para a região metropolitana. Nesse sentido, foi proposta uma linha para ligar o centro do rio de Janeiro à Niterói, passando sob a Baía de Guanabara. Mas de acordo com o Plano essa linha só poderia ser construída quando Niterói e arredores estivessem suficientemente desenvolvidos. Como medida para um futuro próximo, o Plano recomendou a criação de um sistema rápido de navegação por meio de lanchas e hidroplanos.

Além do aperfeiçoamento dos meios de transporte, Agache defendeu a ideia que uma cidade moderna deveria incluir em seu programa campos de esportes, praças, jardins e grandes parques, "ao lado dos palácios administrativos, dos halls de exposições, das casas do povo, das bibliotecas, dos museus, das escolas primárias ou superiores". (AGACHE, 1930, p. 129) 
Assim, da reunião desses elementos Agache chegou aos grandes centros monumentais, que associados aos edifícios comerciais traduziriam o ideal econômico e social da época.

O bairro do Castelo foi, então, destinado aos prédios das grandes administrações, jornais, clubes e hotéis, que se desenvolviam ao redor de uma praça, de onde irradiavam avenidas destinadas a garantir fácil circulação.

Este grande centro monumental, também chamado de Entrada do Brasil seria, portanto, a porta de entrada da cidade do Rio de Janeiro, que no diagrama apresentado na Figura 14 se conecta, no Calabouço, à Porta de Niterói.

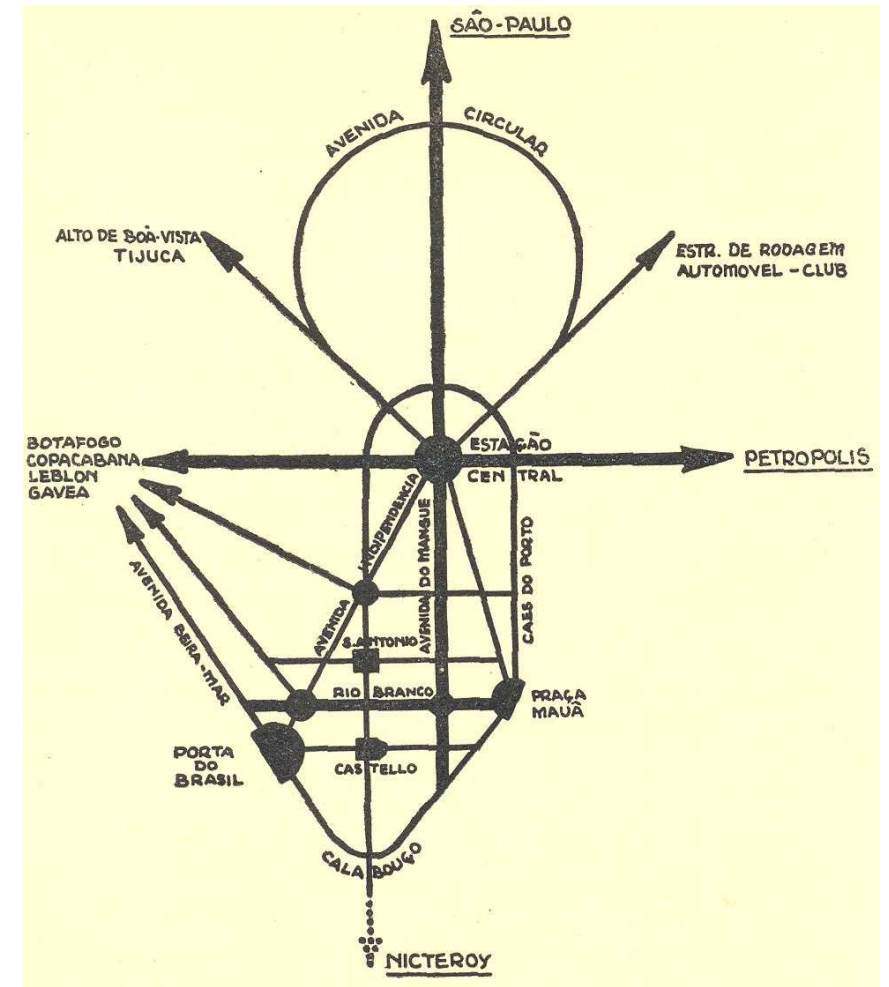

Figura 14: Conexão dos principais eixos viários do Plano Agache. Fonte: OLIVEIRA, 2009.

Também na tese defendida por Attilio, a ligação entre Niterói e Rio de Janeiro deveria ocorrer no trecho de menor distância entre as duas cidades: Gragoatá Calabouço, onde a tese situou a Entrada de Niterói.

Na Entrada do Brasil foi prevista a instalação do centro governamental federal em uma grande área de onde partiam duas avenidas com largura de 64m, uma conduzindo ao Centro de Negócios e a outra chegando até a Estação Central e as estradas que levavam ao interior. A grande praça $(350 \times 350 \mathrm{~m})$, em forma de URBANA, V.5, no 7, out.2013 - Dossiê: Urbanistas e Urbanismo: a escrita da história... - CIEC/UNICAMP 
hemiciclo aberto para a baía, com capacidade para 100 mil pessoas e concebida para "representar um papel decorativo", foi fechada ao fundo por três grandes edifícios: o Senado, a Câmara dos Deputados e um grande auditório para congressos, festas e concertos. (Figura 15)

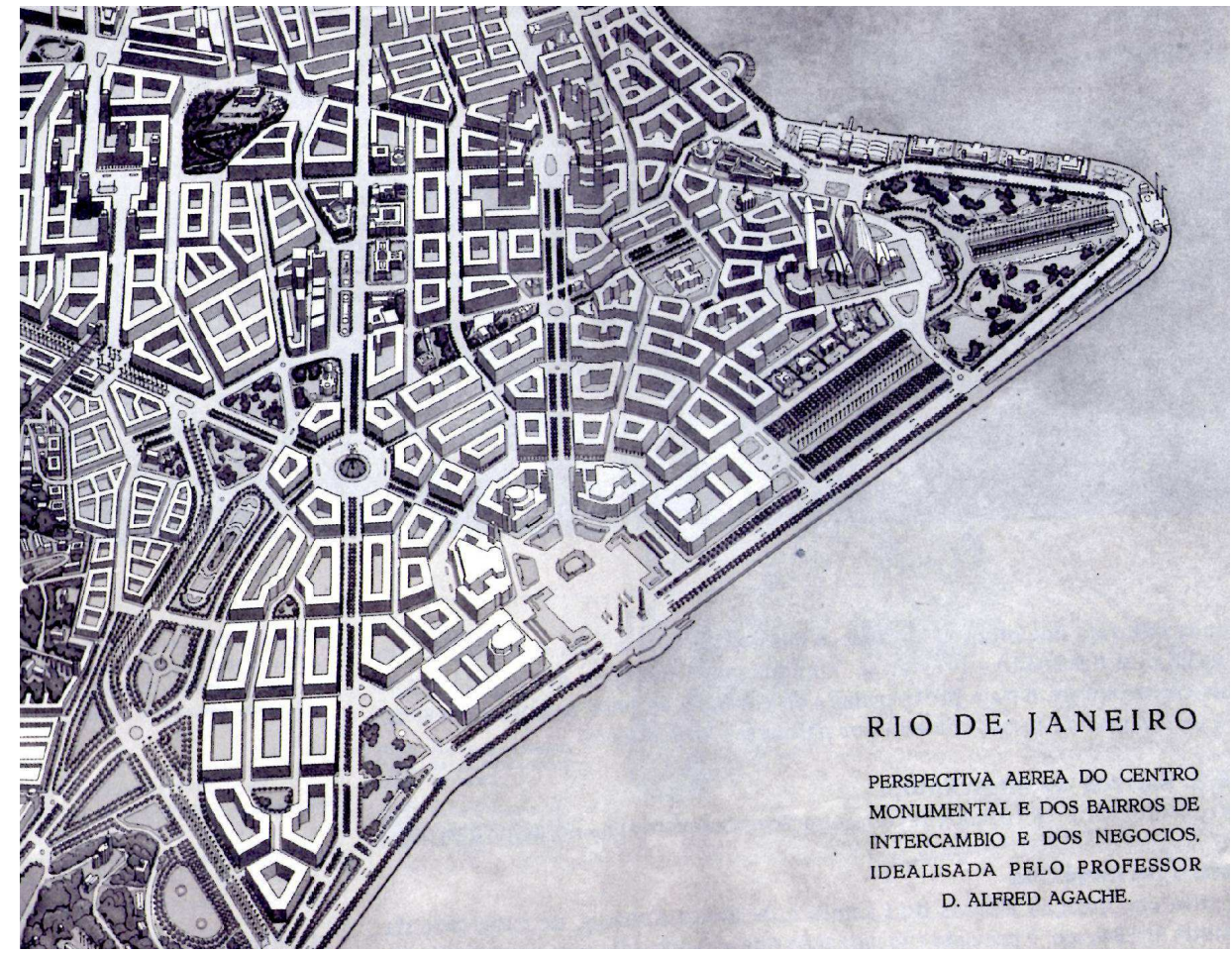

Figura 15: Perspectiva do centro monumental do Plano Agache. Fonte: OLIVEIRA, 2009.

Outra questão abordada por Agache foi a aplicação do zoneamento e a criação de um conjunto de regulamentos, responsáveis por uma configuração urbana ideal. Os regulamentos deveriam prever maior altura para os edifícios destinados ao uso comercial, adensando os bairros centrais, e sua redução nos bairros residenciais à medida que os mesmos ganhassem a periferia. A transição de parâmetros, passandose, segundo as zonas, dos arranha-céus comerciais e prédios de apartamentos residenciais à habitação familiar que se dispersava em moradias individuais até a zona rural. Agache dividiu a cidade em cinco zonas: a) zona central com parte comercial, b) zona industrial e do porto, c) zona residencial, d) zona suburbana, e) zona dos espaços livres e reservas arborizadas. As favelas foram vistas por Agache como uma das chagas da cidade do Rio de Janeiro, "na qual será preciso (...) levarIhe o ferro cauterizador". Descritas como insalubres, sem arruamento e abastecimento de água potável, as favelas, pela situação de precariedade em que se URBANA, V.5, no 7, out.2013 - Dossiê: Urbanistas e Urbanismo: a escrita da história... - CIEC/UNICAMP 
encontravam, foram apontadas no Plano como "uma ameaça para o conjunto da coletividade urbana". (idem, p. 240) (Figura 16)

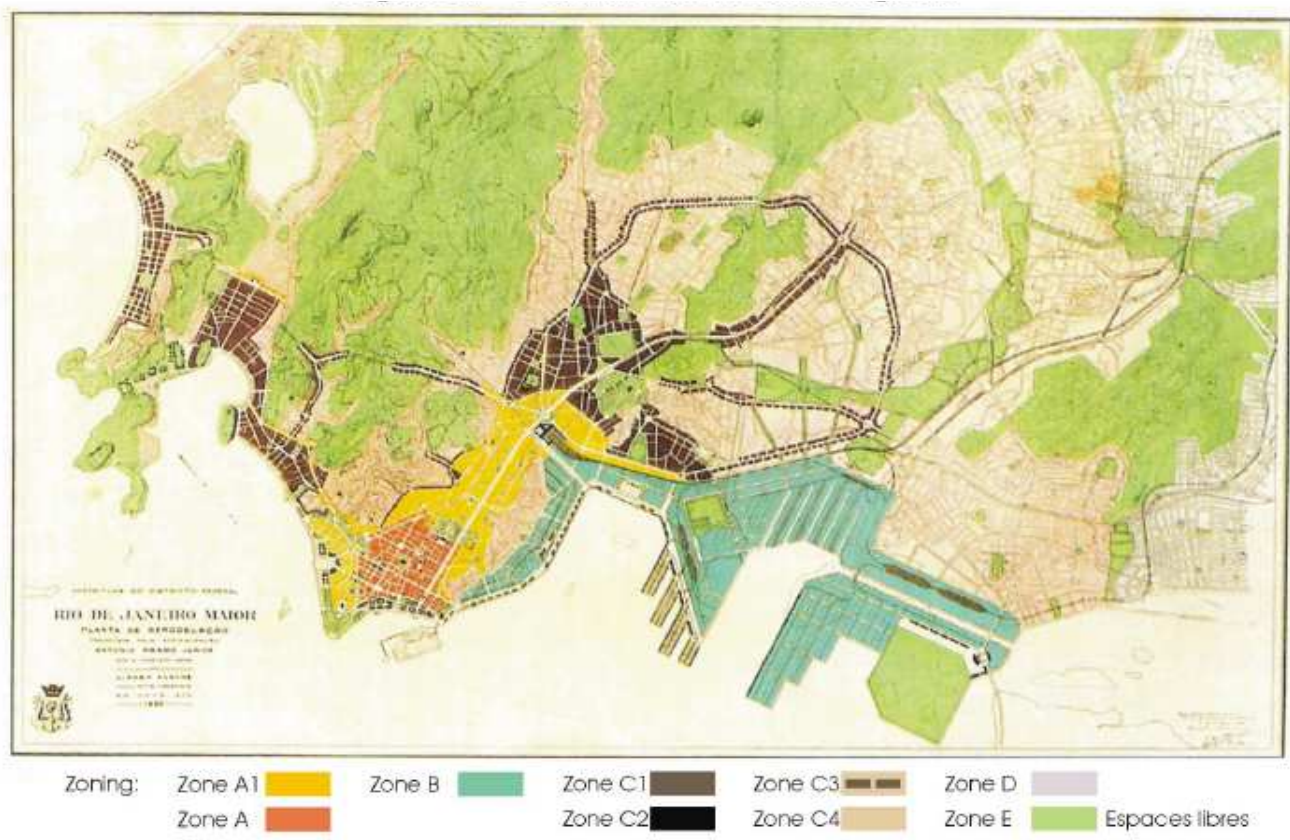

Figura 16: Proposta de zoneamento do Plano Agache. Fonte: BORGES, 2007.

Também foi proposta uma Cidade Universitária no bairro de Botafogo, com uma superfície de cerca de 450 mil metros quadrados ao pé do morro da Babilônia, entre as Avenidas Pasteur e Wenceslau Braz e a praça Juliano Moreira. Na Praia Vermelha, estariam as habitações destinadas aos estudantes, análogas à Cité Universitaire de Paris. O conjunto também contaria com um clube de reuniões, uma pequena enfermaria e algumas habitações destinadas a professores, na encosta do Morro da Babilônia.

Segundo Agache, a vida urbana do Rio de Janeiro era organizada conforme certos elementos funcionais complexos e especializados, sendo que alguns se desenvolviam normalmente, como a função residencial de alguns bairros como Laranjeiras, Copacabana, Ipanema e Lagoa, e outros de maneira caótica, como o que ocorria nos bairros das classes operárias e também com relação à concentração de bancos e casas de comércio em ruas estreitas e à ausência de um bairro industrial.

Na formulação da "ossatura do plano diretor" foi estudada a adaptação dos elementos funcionais ao meio, bem como a sua distribuição lógica na cidade. Assim, cada elemento funcional da cidade passou a ser objeto de um estudo, sendo URBANA, V.5, no 7, out.2013 - Dossiê: Urbanistas e Urbanismo: a escrita da história... - CIEC/UNICAMP 
designados os seguintes elementos funcionais: Posto de Comando, Bairros de Intercâmbio, Bairros de Abastecimento, Bairro Industrial, Portos, Bairros Residenciais, Bairros Universitários e Espaços Livres.

Outra parte do Plano, voltada para a infraestrutura urbana, avaliou minuciosamente as condições naturais da cidade e apresentou um estudo sobre a situação sanitária dos bairros insalubres, do escoamento das águas pluviais, da adução, do abastecimento de água e das águas residuais.

Como ponto nodal do Plano estava a reestruturação viária da cidade e a reorganização dos meios de transportes, sendo considerado o tráfego a longa distância, o de extensão, bem como o metropolitano. A proposta também incluiu a substituição dos bondes, incapazes de desenvolver a velocidade exigida pela cidade, a criação de vias arteriais principais que penetrariam até o centro da cidade e de vias de comunicação com os bairros excêntricos. Em termos metropolitanos, o Plano justificou a importância da construção de uma rede rápida estendida na direção das novas praias e aglomerações satélites, como Niterói, que foi considerada mais próxima do centro do Rio que alguns subúrbios, sendo apontada a necessidade de um serviço de barcos a gasolina mais rápido que os ferryboats para comunicar o cais Pharoux com os pontos de atração na margem oposta.

De modo geral, percebe-se a grande aproximação entre o Plano de Agache e a tese de Correa Lima, ainda que o primeiro tenha um caráter prático, como plano de remodelação da cidade do Rio de Janeiro, então Distrito Federal; e o segundo, uma tese de doutorado, de tratamento mais genérico da cidade de Niterói.

"Avant- Projet" de Niterói e Plano Agache no Rio de Janeiro: Influências e vestígios

A análise das propostas da tese do Arquiteto mostra referências claras ao urbanismo da época e pode ser feito um paralelo com o Plano Agache, realizado na mesma época para o Rio de Janeiro, guardando-se a distância que separa uma tese de um trabalho proposto para ser implementado.

No caso do "Avant-Projet", alguns preceitos teóricos foram claramente explicitados e tomaram a primazia no encaminhamento das propostas. A ênfase dada à circulação viária, num momento em que esta ainda não constituía um problema, numa cidade de 100.000 habitantes, antes do advento do automóvel, evocou Henard e sua URBANA, V.5, no 7, out.2013 - Dossiê: Urbanistas e Urbanismo: a escrita da história... - CIEC/UNICAMP 
Théorie généraIe de Ia circuIation. A fórmula desse autor para o "nó" de circulação foi citada na tese.

A cidade-jardim de Piratininga, correspondendo ao rebatimento de Copacabana, no Rio de janeiro, buscou em Howard seu embasamento teórico: "nous prévoyons Ia cité construite suivant Ies príncipes de Howard, construite de toutes pièces, pouvant vivre par ses propes moyens, et avec une population à 20.000 habitants". (LIMA, 1932)

A solução do engenheiro sanitarista Saturnino de Brito para a Lagoa Rodrigo de Freitas, no Rio de Janeiro, foi prevista para a lagoa de Piratininga, visando a sua salinização e renovação, evitando a estagnação das águas.

Interessante notar que a citação de Le Corbusier referiu-se a uma opinião emitida pelo arquiteto, em uma de suas viagens ao Brasil com relação à aeração das casas de favela: "il a trouve pIus logique et conforme aux besoins, en opposition à ceIIe de I'élite, trop prétentieuse et combiée de préjugés" ${ }^{15}$. Mas a tese não deixou de assinalar que essa forma de moradia oferecia todos os inconvenientes higiênicos e morais largamente estudados no mundo inteiro e defendeu a construção de moradias individuais econômicas sob a responsabilidade do Estado.

O projeto-tese, sem maior compromisso com a sua viabilidade, trouxe sugestões que foram incorporadas posteriormente, cujos vestígios procuramos recuperar.

A adoção de algumas idéias, como a abertura da futura Avenida Amaral Peixoto, com a exigência das construções com galerias cobertas, o aterrado do Centro, o túnel de Piratininga (no atual plano diretor), ainda não está devidamente correlacionada ao grau de influência desse plano para as futuras tomadas de decisão nas intervenções da cidade. No entanto, permite levantar algumas hipóteses sobre a sua apropriação nos projetos realizados, pós anos 1930. A presença e proximidade de Attilio Correa Lima com o governo federal e estadual no período Vargas - Amaral Peixoto ${ }^{6}$, através de seus planos para a cidade industrial de Volta Redonda e outros municípios fluminenses, pode ter permitido a veiculação de algumas propostas de intervenção na cidade de Niterói.

\footnotetext{
${ }^{5}$ Attilio cita o livro Précisions, em preparação por Le Corbusier, na época.

${ }^{6}$ O Almirante Amaral Peixoto, genro do Presidente Vargas foi interventor do Estado do Rio de Janeiro durante o período Vargas (1930-1945).
}

URBANA, V.5, no 7, out.2013 - Dossiê: Urbanistas e Urbanismo: a escrita da história... - CIEC/UNICAMP 
Alguns aspectos foram determinantes para a elaboração do trabalho da tese: a similaridade de Niterói com o Rio de Janeiro, a ligação entre as duas cidades e o uso de princípios urbanísticos da época.

Com relação a essa similaridade na ocupação do solo, ela foi marcada pelo geógrafo Geiger (GEIGER, 1961 p.312): "Nesse sentido, certos setores da capital carioca tem traçados semelhantes aos de Niterói; nesta cidade igualmente, o relevo, ainda que menos rigoroso, determinou geralmente as formas de sua ocupação. Constata-se que nas duas cidades, os centros de atividades se encontram nas proximidades da estreita entrada da baía. As classes sociais elevadas, nas duas cidades, instalaram-se na costa, ao sul, ou nos vales e encostas de suas respectivas zonas setentrionais. As zonas industriais são paralelas, nas margens pantanosas do interior da baía, enquanto que as classes populares fixaram-se nos subúrbios da zona norte, onde se encontram igualmente os estabelecimentos industriais".

A ligação entre as duas cidades só foi efetivada em 1974, através de ponte, em local não previsto por Attilio, junto ao porto de Niterói. Mas, o acesso da ponta do Gragoatá defendido por ele consta do projeto do metrô do Rio de janeiro, caso ele venha a se estender para Niterói.

Por outro lado, as demais intervenções urbanas que se concretizaram posteriormente: abertura da Av. Amaral Peixoto (1942), ocupação das praias da zona sul e da Região Oceânica pelas classes de renda mais elevadas, abertura de túneis, arrasamento de morros e aterros da área central já tinham sido indicadas pelas propostas contidas na tese. Evidentemente, as formas de intervenção e de apropriação dos novos espaços da cidade se deram de forma pontual e "espontânea", não precedidas de planos globais, caracterizando-se pela fragmentação das medidas ao longo de quase seis décadas.

O plano de extensão, remodelação e embelezamento foi oficialmente entregue à prefeitura do Rio de Janeiro após o retorno de Alfred Agache à França, devido à Revolução de 1930. Em 1931, Adolfo Bergamini chegou à administração da cidade. Como sucessor de Prado Júnior, Bergamini instituiu uma comissão para avaliar o Plano Agache, presidida pelo engenheiro Armando Augusto de Godoy e integrada pelos arquitetos Lúcio Costa, Arquimedes Memória, Ângelo Bruhns, e pelos engenheiros Henrique de Novais, Raul Pederneiras e José Marianno Filho. Em 1934, apesar do parecer favorável da comissão de avaliação, o prefeito Pedro Ernesto 
Baptista optou pelo arquivamento do plano, dentro do espírito de rejeição desenvolvido pela Revolução de 30 às ações do governo anterior. Outra razão para que o plano não tenha sido implantado pode ser compreendida pela grande revolução que estava acontecendo no urbanismo naquela época, provocada pelo movimento modernista em torno dos congressos CIAM.

Mais tarde, algumas ideias do Plano Agache foram resgatadas pelo governo do prefeito interventor Henrique de Toledo Dodsworth, no Estado Novo, reativando a Comissão do Plano da Cidade a fim de adaptar o projeto de Alfred Agache à situação da época. O Plano da Cidade elaborado por esta nova comissão e sancionado em diferentes decretos de 1938 a 1948 extraiu do Plano Agache todos os estudos sobre os principais eixos viários da cidade e implantou com base nesses projetos uma etapa de construção de túneis, viadutos e estradas.

A idéia de aplicar o zoneamento como meio de controlar o uso do solo urbano, já apresentada no Plano de Agache, continuou sendo perseguida pelos profissionais responsáveis pelo desenvolvimento da cidade. Em 1937, foi aprovado um instrumento legal, o Decreto no 6.000, de 1 de julho, que organizou de forma sistemática a regulamentação urbana da cidade, através da codificação da legislação edilícia, a definição do zoneamento e a introdução da defesa dos aspectos paisagísticos e do patrimônio histórico.

O Decreto n 6.000 se tornou uma consolidação dos estudos apresentados pelo Plano Agache e uma conseqüência da evolução da legislação urbanística iniciada com o Decreto no 1.594/1914 em decorrência da expansão do Rio de Janeiro. Esse instrumento legal regulou durante 30 anos o uso e a ocupação do solo urbano do Rio de Janeiro quando foi substituído pela Lei no 1574, de 11 de dezembro de 1967 que estabeleceu normas para o desenvolvimento urbano e regional do então Estado da Guanabara.

A Comissão do Plano da Cidade foi responsável por elaborar um plano geral de transformação e extensão da cidade, que se tornou um grande projeto de realizações de obras e conseguiu atingir seus objetivos em face de sua vinculação direta à Secretaria Geral de Viação, Trabalho e Obras Públicas. Durante a ditadura de Getúlio Vargas, algumas propostas do plano foram sendo adaptadas à realidade da época e tiveram sua implantação, como a Avenida Presidente Vargas, a Esplanada do Castelo, 
a Avenida Brasil e a execução de vários projetos para área do morro de Santo Antônio.

Finalmente, cabe considerar a importância desses documentos que reafirmaram a tendência constatada quando foram comentados os projetos premiados para a nova capital da Austrália, em 1912:

"Ces projets présentent quelques-une des caractéristiques des plans d'urbanisme du début du XXe. siecle : de grands axes qui viennent buter sur des ensembles monumentaux majeurs, des avenues radiales qui se combinent à des rues locales et rectilignes, l'accent mis sur les caractéristiques visuelles plutôt que sur les détails de construction, et l'abondance des parcs et des équipements de loisir". (REPS, 1997, p.166)

\section{Referências bibliográficas}

ABREU, Mauricio A (1988). Evolução Urbana do Rio de Janeiro. Rio de Janeiro: Iplan-Zahar.

ACKEL, Luis Gonzaga Montans (2007). Attílio Corrêa Lima, uma trajetória para a modernidade. São Paulo: Tese de Doutorado, FAU/USP.

AGACHE, Alfred Hubert (1930). Cidade do Rio de Janeiro, extensão, remodelação, embelezamento. Paris: Foyer Bresilien.

AZEVEDO, Marlice Nazareth Soares de (1999). A Construção da cidade na primeira metade do Século XX: Niterói, espelho do Rio. In LEME, Maria Cristina Leme (coord.) Urbanismo no Brasil - 1895 -1965. São Paulo: Studio Nobel: FAU/USP, FUPAM.

(2010). Attilio Corrêa Lima (1901/1943):

Uma produção moderna em diferentes escalas - do objeto à cidade, Simpósio Temático Percursos profissionais: Arquitetos e Urbanistas, a contribuição para a teoria e a prática no Brasil, 1920-1960. Rio de Janeiro: Anais do I ENANPARQ.

BORGES, Marília Vicente (2007). O zoneamento na cidade do rio de janeiro: gênese, evolução e aplicação. Dissertação de mestrado. Rio de Janeiro: IPPUR. CHOAY, Françoise e MERLIN, Pierre (1988). Dictionnaire de L'urbanisme et L 'Aménagement. Paris: Presses Universitaires de France. 
GEIGER, Pedro P. Aspectos do fato urbano no Brasil (abril/junho, 1961). Rio de Janeiro: Revista Brasileira de Geografia.

LIMA, Attílio Correa Lima (1932). Tese Avant Projet d'aménagement et extension de de la ville de Niterói au Brésil. Paris.

OliVeIRA, Sônia M. Q. de (org.) (2009). Planos Urbanos do Rio de Janeiro: Plano Agache. Rio de Janeiro: Centro de Arquitetura e Urbanismo.

REZENDE, Vera (1982). Planejamento urbano e ideologia: quatro planos para a cidade do Rio de Janeiro. Rio de Janeiro: Civilização Brasileira.

In Leme, Maria Cristina da Silva (org.) (1999). Urbanismo no Brasil, 1895-1965. São Paulo: Studio Nobel, FAU-USP, FUPAM.

PROST, Henri (1932). Préface. Avant -Projet d'Amenagement et d' Éxtension Niterói, René Blamon, Jean Kahane \& Cie. Paris.

REPS, J. Canberra (1912). Carlton South: Melbourne University Press, 1997.

SÁNCHEZ, Inés de Madariaga (1999). Introdución al Urbanismo. Conceptos y métodos de la planificación urbana. Madrid: Alianza Editorial. 